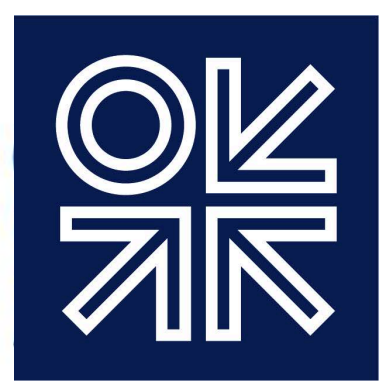

THE OXFORD

INSTITUTE

FOR ENERGY

STUDIES

November 2017

\title{
The potential market for LNG in the Caribbean and Central America
}

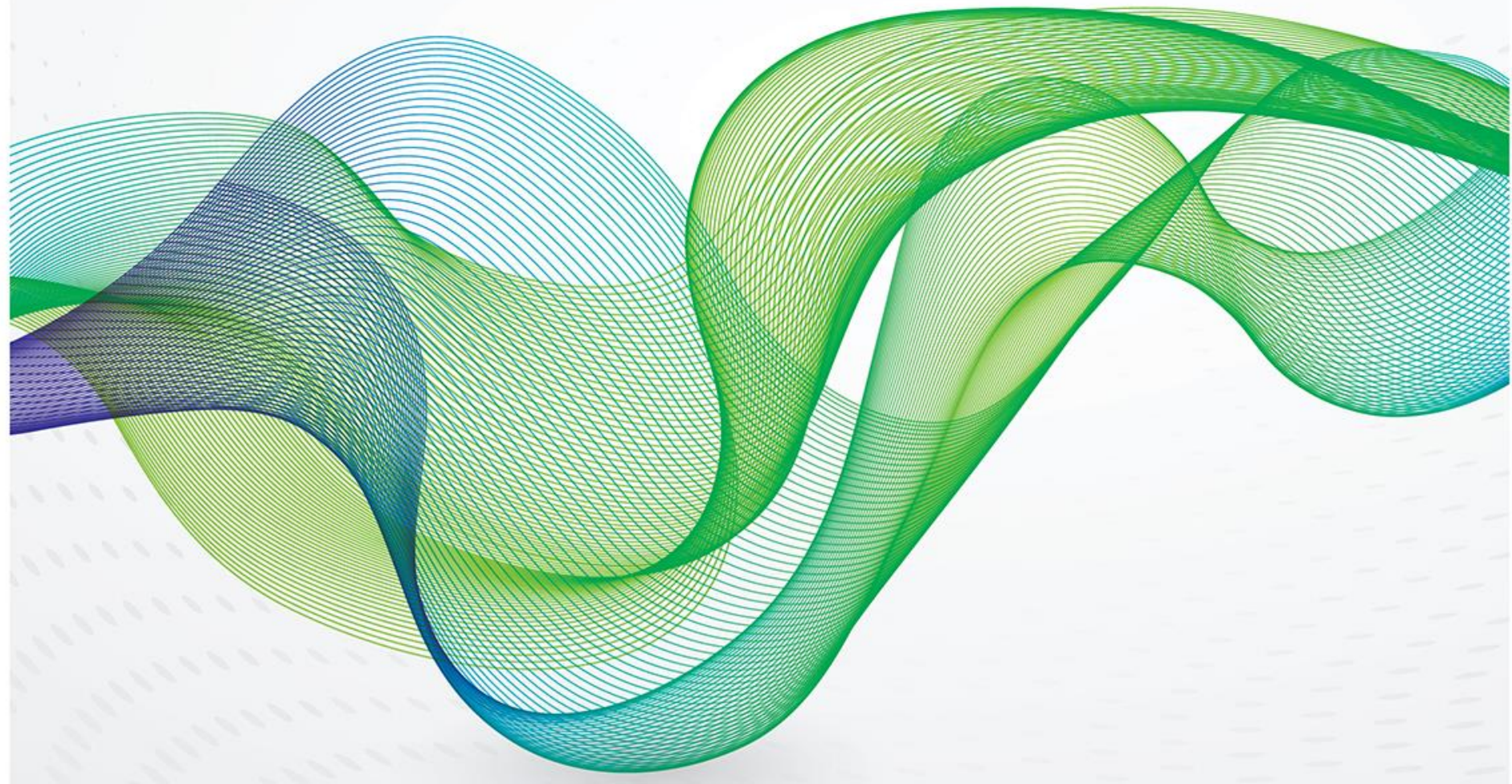



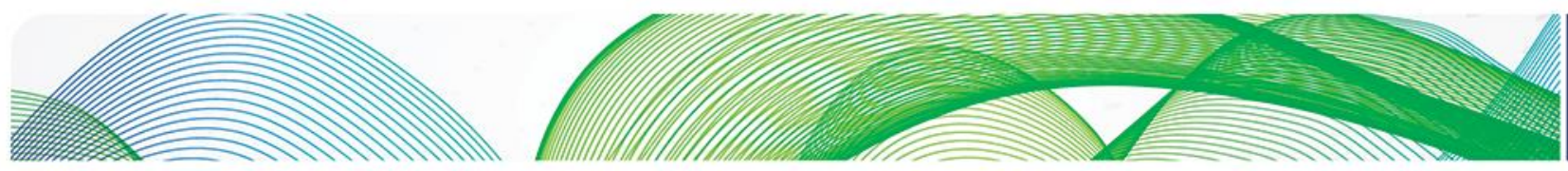

\section{잊조}

The contents of this paper are the authors' sole responsibility. They do not necessarily represent the views of the Oxford Institute for Energy Studies or any of its members.

Copyright $\odot 2017$

Oxford Institute for Energy Studies

(Registered Charity, No. 286084)

This publication may be reproduced in part for educational or non-profit purposes without special permission from the copyright holder, provided acknowledgment of the source is made. No use of this publication may be made for resale or for any other commercial purpose whatsoever without prior permission in writing from the Oxford Institute for Energy Studies.

ISBN 978-1-78467-098-6

DOI: https://doi.org/10.26889/9781784670986 

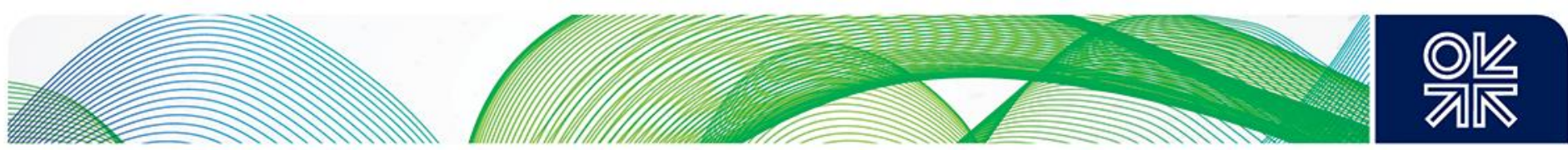

\section{Acknowledgements}

The authors would like to express their gratitude to those who provided useful insights, in particular Tito Sanjurjo and Donald Hubbard, who provided insightful comments about small LNG projects in the Caribbean.

We would like to thanks James Henderson, director of OIES Natural Gas Programme, for his guidance and useful comments, as well as John Elkins and Kate Teasdale for the final review and commenting the paper. 

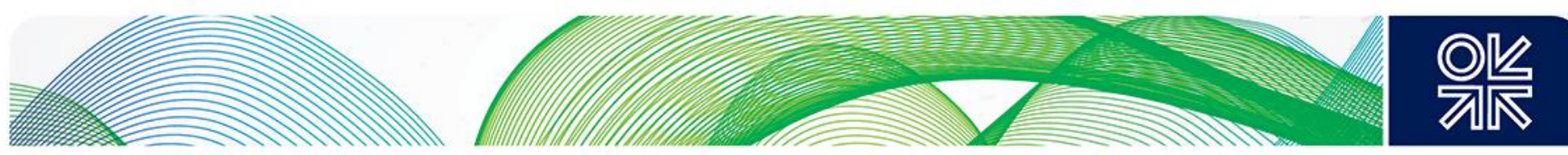

\section{Preface}

If gas is to have a secure long-term future in the global energy mix, then it is likely that the industry will need to come up with creative and innovative ideas to develop new markets, especially in regions where demand may never match the large volumes imported by traditional buyers such as Japan, South Korea and Taiwan. Naturally LNG suppliers are likely to focus on large and growing markets such as China as they seek to find markets for their new developments, but smaller markets can also be of interest, especially if the competing fuels are relatively high cost liquids such as diesel and heavy fuel oil.

The countries of the Caribbean provide a useful example of just such markets, and Martin Lambert and leda Gomes have provided in this working paper a fascinating insight into the current and potential role of gas in the region. They review the current role of gas in the key countries, examine case studies of innovative business models that are being used to expand gas consumption and analyse the competitive position of gas relative to the alternative fuels on offer, especially in the power sector.

Importantly, the authors also draw conclusions for the broader gas industry in terms of the key issues in developing new smaller markets, and suggest lessons that can be learned from their analysis of the Caribbean. As such, although the markets they describe are small in themselves, the example that they provide can offer significant scope for understanding how small markets in a number of other regions could be developed in the coming years, potentially providing a new area of growth for the global gas industry.

James Henderson

Director, Natural Gas Programme, OIES 


\section{Contents}

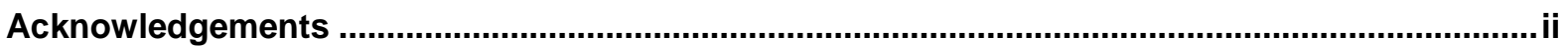

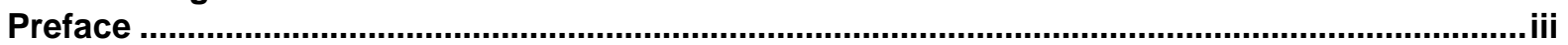

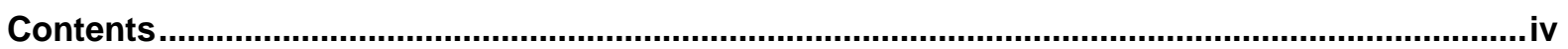

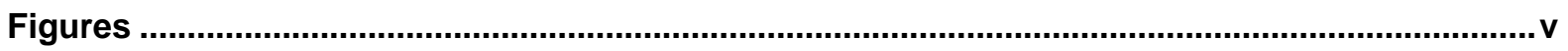

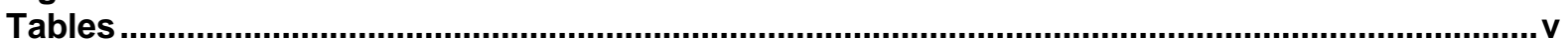

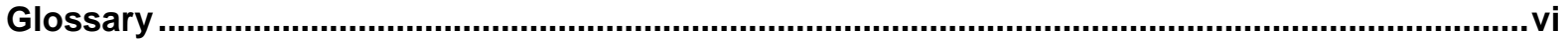

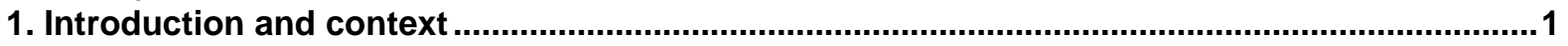

2. Potential market for LNG in the Caribbean and Central America ...........................................1

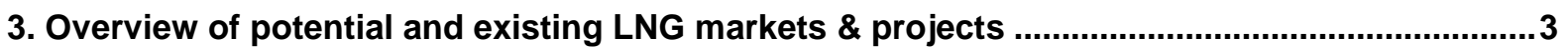

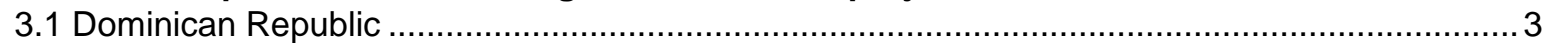

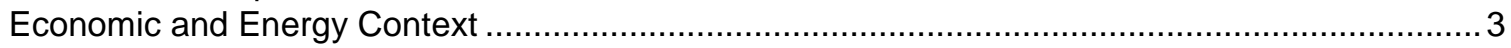

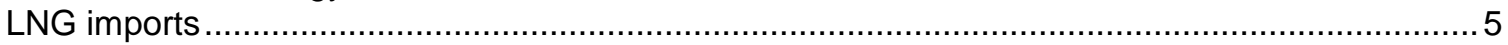

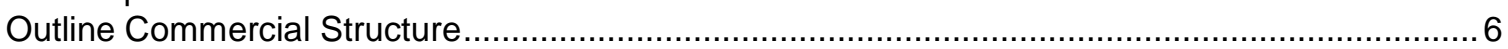

Future developments and evolving business models ................................................................ 7

Other proposed LNG projects, residual demand and growth ...................................................

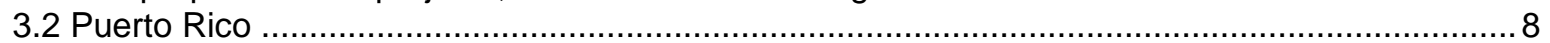

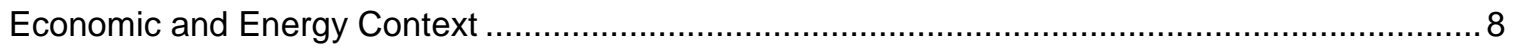

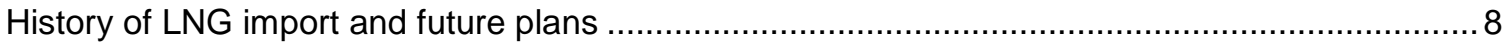

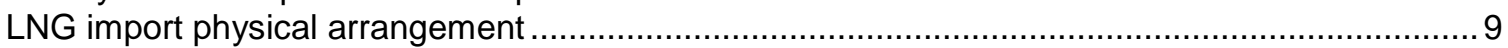

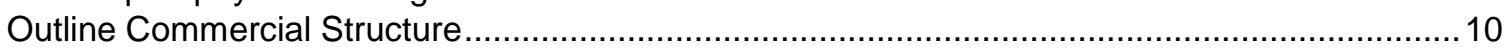

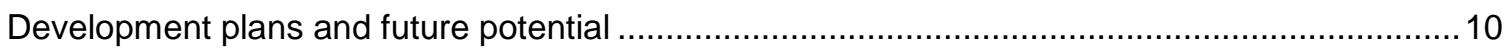

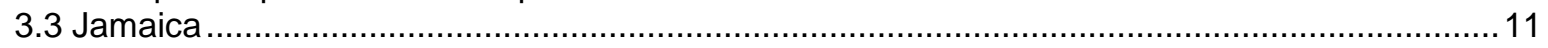

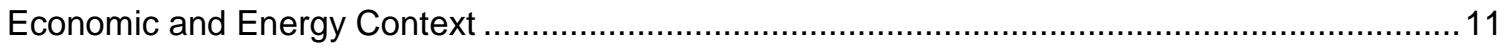

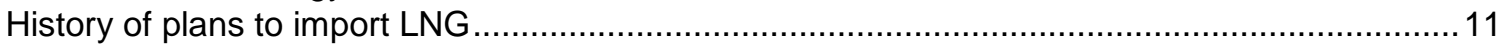

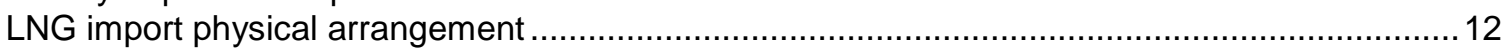

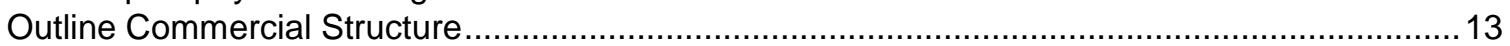

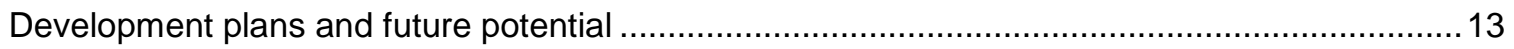

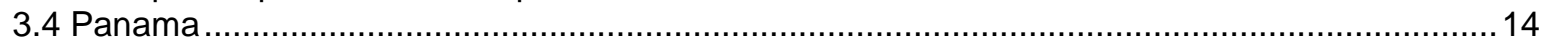

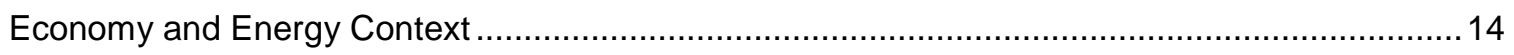

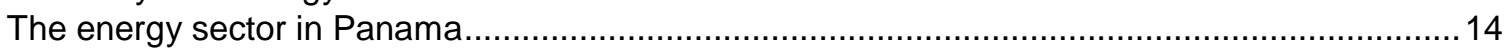

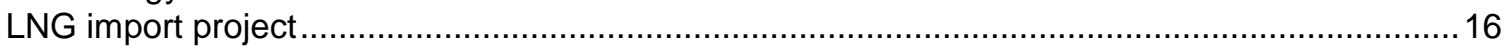

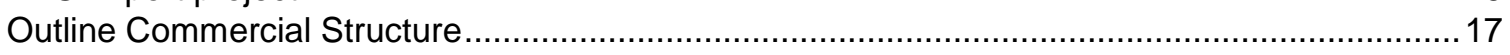

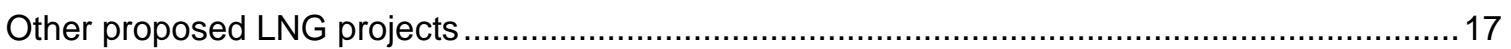

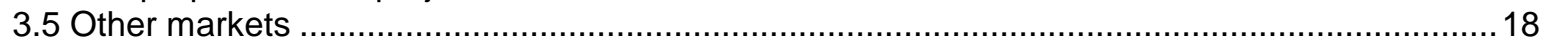

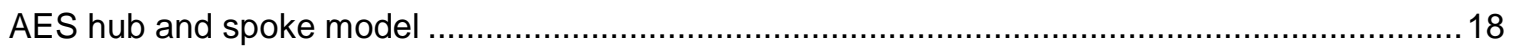

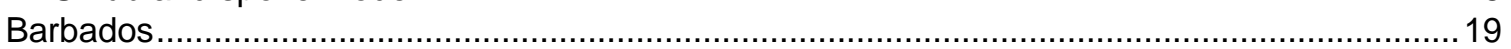

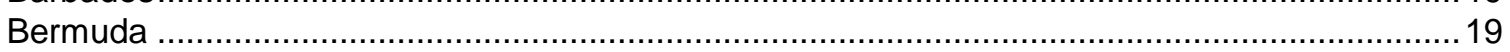

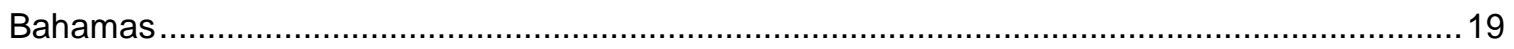

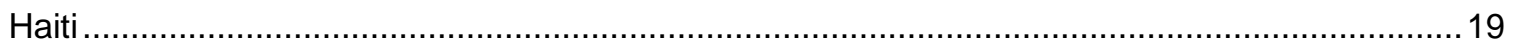

4. Logistics, operational and commercial issues: LNG and small markets.................................20

5. Electricity pricing policies and regulation of the gas and electricity markets ..........................21

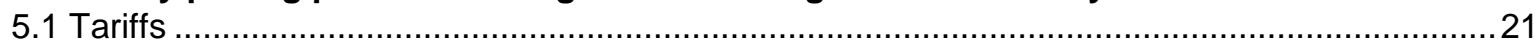

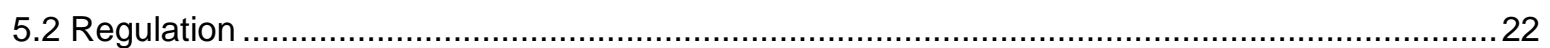

6. Analysis of the commercial model and economics of selected projects .................................23

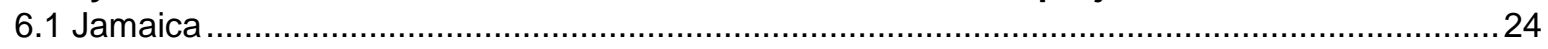

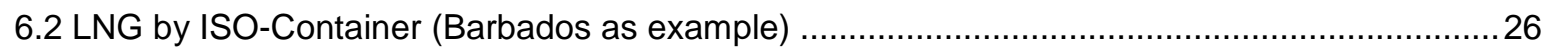

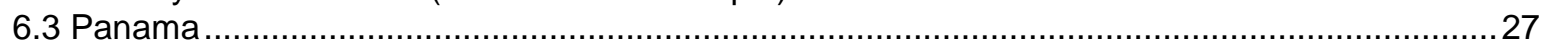

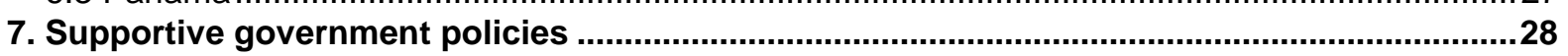

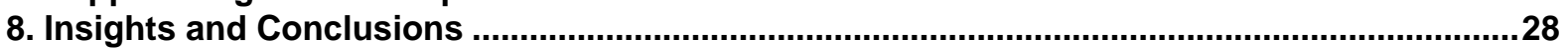

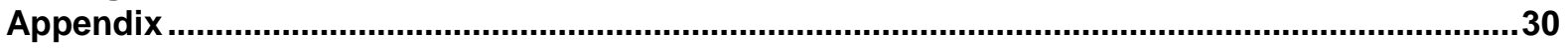



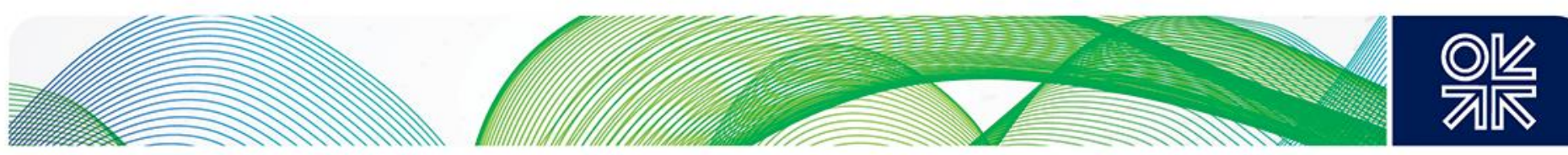

\section{Figures}

Figure 1: Central America and Caribbean: installed power generation capacity (MW) .......................2

Figure 2: Dominican Republic: key energy data (MTOE) - 2014 ................................................ 4

Figure 3: Dominican Republic - AES Andres LNG terminal.......................................................

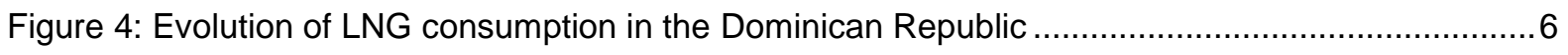

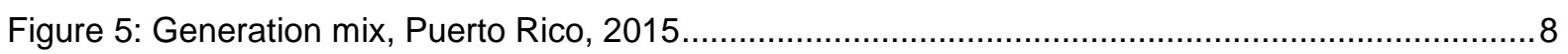

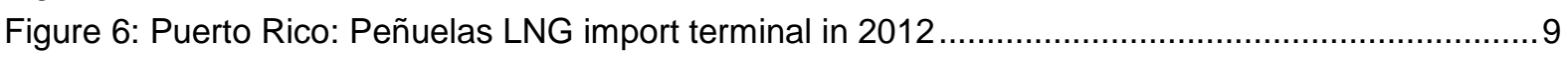

Figure 7: Puerto Rico- Proposed Natural Gas pipelines ............................................................ 10

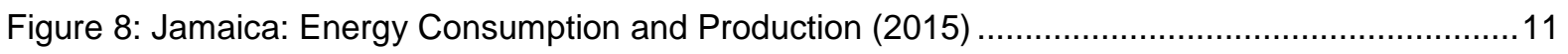

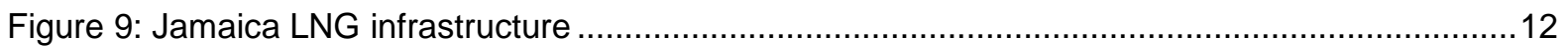

Figure 10: Panama vs Latin American and the Caribbean GDP growth $(\%)$.....................................14

Figure 11: Panama: evolution of the supply of energy ................................................................ 15

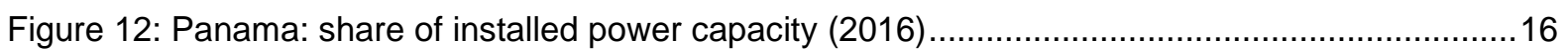

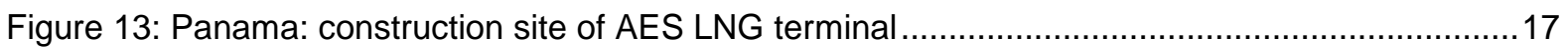

Figure 14: Proposed Hub and Spoke LNG distribution mode for Central America and Caribbean ...... 18

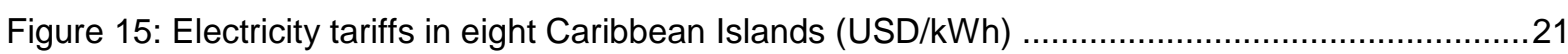

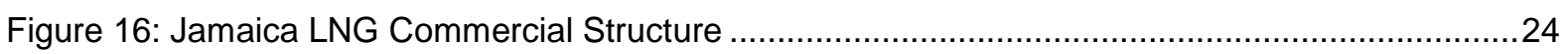

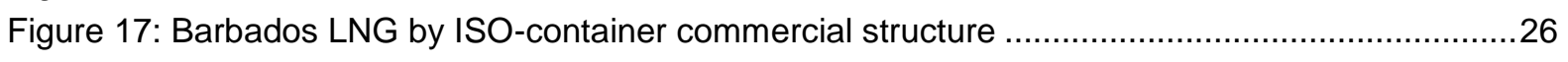

Figure 18: Panama: Regasified LNG competitiveness vs HFO and diesel .....................................27

\section{Tables}

Table 1: Caribbean and Central America: addressable market for $L N G$ for power generation ..............3

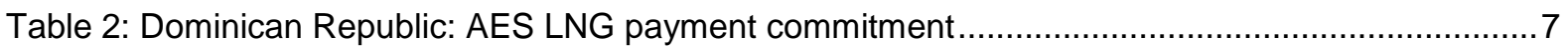

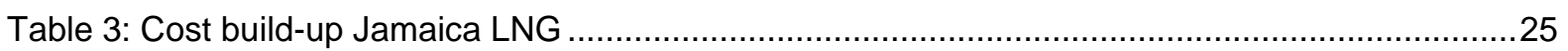

Table 4: Caribbean and Central America: demographics and generation capacity .............................30

Table 5: Caribbean and Central America: power generation capacity and gas supply potential ..........31

Table 6: Credit rating of select Caribbean and Central America countries .........................................32 


\section{Glossary}

Bcma

CNE

DR

FERC

FSU

GDP

GNF

GW

HFO

JPS

LNG

$\mathrm{m}^{3}$

MEM

mmscf

Mtoe

mtpa

MW

MWh

NFE

NREL

NYMEX

OEA

PREPA

SENI

TBtu

TWh

US CPI
Billion $\left(10^{9}\right)$ cubic metres per annum

National Energy Commission (in DR)

Dominican Republic

US Federal Energy Regulatory Commission

Floating Storage Unit

Gross Domestic Product

Gas Natural Fenosa

Giga Watts

Heavy Fuel Oil

Jamaica Public Service - the national power utility

Liquefied Natural Gas

Cubic metres

Ministry of Energy and Mines (in DR)

Million standard cubic feet

Million tonnes of oil equivalent

Million tonnes per annum

Mega Watts

Mega Watt hour

New Fortress Energy

National Renewable Energy Laboratory (US)

New York Mercantile Exchange

Organisation of American States

Puerto Rico Electric Power Authority

National Integrated Energy System (in DR)

Trillion (1012) British Thermal Units

Tera $\left(10^{12}\right)$ Watt hours

Consumer Price Index in the United States of America 

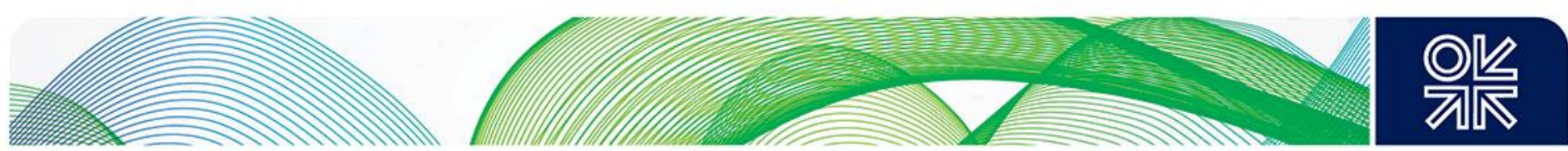

\section{Introduction and context}

The Caribbean has been described as a potentially ideal region for LNG imports due to its present dependence on diesel and fuel oil for power generation, high electricity tariffs and its proximity to regional LNG suppliers in Trinidad \& Tobago and on the US Gulf Coast.

The ability to switch from liquid fuels to natural gas is being pursued as a way to lower costs and bring environmental benefits.

In 2016 the region imported only 2.08 mtpa of LNG, circa $0.8 \%$ of the world trade. Until 2016 there were only two LNG import terminals in the region: in the Dominican Republic and Puerto Rico.

In 2016 two more countries joined the club of LNG importers, Colombia (Cartagena LNG) and Jamaica with Panama slated to start-up in 2019. Colombia had initially envisaged importing LNG on the Caribbean coast and exporting LNG from the Pacific Rubiales project, but the latter has been halted due to market conditions and its sponsor's financial issues. While Colombia is technically part of the Caribbean, its characteristics, with an established gas industry and a large reliance on hydro power generation, make it rather different from other Caribbean markets, so is not considered in detail in this paper.

The region is also of interest to the wider LNG industry, as some of the technical, commercial and logistical innovations being developed for the Caribbean may be useful models for developing smaller potential LNG markets elsewhere in the world (e.g. in Africa, SE Asia, Mediterranean islands). While other parts of the world have struggled to progress LNG import plans, new projects have been developed in the Caribbean, such as in Jamaica and Panama, both relying on supply to power plants and alternative business models appropriate to the local markets. The small size of the markets presents logistic and commercial challenges for the supply of LNG and for financing the projects.

This working paper provides an overview of the Caribbean markets and the potential for LNG imports across the region. It also investigates the key commercial, logistics and regulatory challenges for the development of a natural gas market in the region.

\section{Potential market for LNG in the Caribbean and Central America}

According to the World Bank1, the Latin America and Caribbean region (LAC) "seems to have turned the corner" after six years of economic stagnation. However, the economic impact of hurricanes Irma, Jose and Maria, which hit the region in September 2017, is yet to be measured but certainly damaged badly the infrastructure of several islands, which are heavily dependent on tourism.

For this paper, the Caribbean comprises the islands and the countries with Caribbean coastal regions and islands, starting from the Bahamas in the north and following the archipelago down south to Trinidad and Tobago. There are 13 independent island nations in addition to territories of France, the Netherlands, the United Kingdom, and the United States of America. The independent nations are Cuba, Jamaica, Haiti, Dominican Republic, The Bahamas, St Kitts \& Nevis, Antigua \& Barbuda, Dominica, St Lucia, St Vincent and the Grenadines, Barbados, Grenada and Trinidad and Tobago. The region also includes the territories of Curacao, Saint Maarten and Aruba (Netherlands), Puerto Rico and US Virgin Islands (USA), Martinique and Guadeloupe (France), British Virgin Islands, Montserrat, and Cayman (UK). The study also covers Central American markets, which have a Caribbean coastal area, including Panama where AES is developing and building the Costa Norte LNG terminal. Colombia has a coastal area facing the Caribbean and commissioned an LNG import 

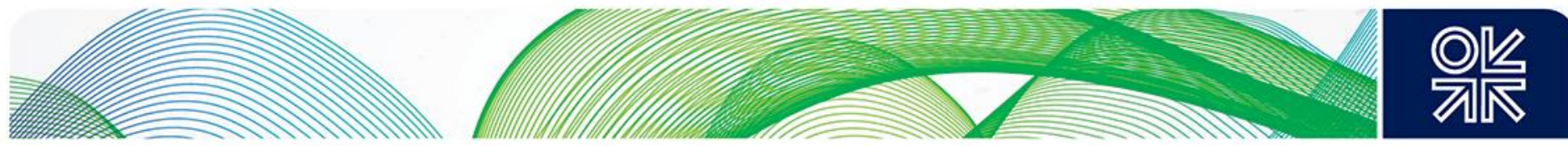

terminal in Cartagena in 2016. However due to the larger size of Colombia's energy market and a relatively deep natural gas market, it faces different challenges when compared to the typical Caribbean and Central American markets. For this reason, this paper does not analyse Colombia's LNG market and projects. As of September 2017, the population in the Caribbean and Central America totalled 73.7 million people with a total power generation installed capacity of $30.6 \mathrm{GW}$, of which $15.0 \mathrm{GW}$ is in the Caribbean Islands' ${ }^{2}$, and $15.5 \mathrm{GW}$ GW in Central America (Appendix, Table $5)$.

The four largest countries in population are Cuba, Haiti, Dominican Republic and Honduras. These countries possess a much lower level of generation capacity per inhabitant, when compared to smaller countries such as Aruba, the Cayman Islands and the US Virgin Islands.

Natural gas is utilised in only a handful of countries: Trinidad \& Tobago (LNG exporter), Dominican Republic, Jamaica and Puerto Rico (LNG importers) and Barbados (domestic gas producer and LNG importer ${ }^{3}$ ). AES is currently building a LNG import terminal in Panama, due for completion in mid2019.

The key common features in the region are summarised below:

- Heavily dependent on fuel oil and diesel for power generation.

- Small-sized electricity markets; industrial market is small and scattered

- Lack of transmission and distribution infrastructure for natural gas

As can be seen in Figure 1 below, only a few countries have generation capacity in excess of 1000 MW, namely Puerto Rico, Cuba, Guatemala, Dominican Republic, Costa Rica, Trinidad \& Tobago, Honduras and Nicaragua. Another handful of countries have generation capacity between $400 \mathrm{MW}$ and $1000 \mathrm{MW}$, namely Jamaica, Guadeloupe, Bahamas and Martinique. There are 14 countries/territories with installed capacity below $100 \mathrm{MW}$ : Turk \& Caicos, British Virgin Islands, Belize, Saint Maarten, Anguilla, Montserrat, Dominica, St. Kitts \& Nevis, Antigua \& Barbuda, Grenada, Curacao, St. Vincent \& Grenadines and Saint Lucia.

\section{Figure 1: Central America and Caribbean: installed power generation capacity (MW)}

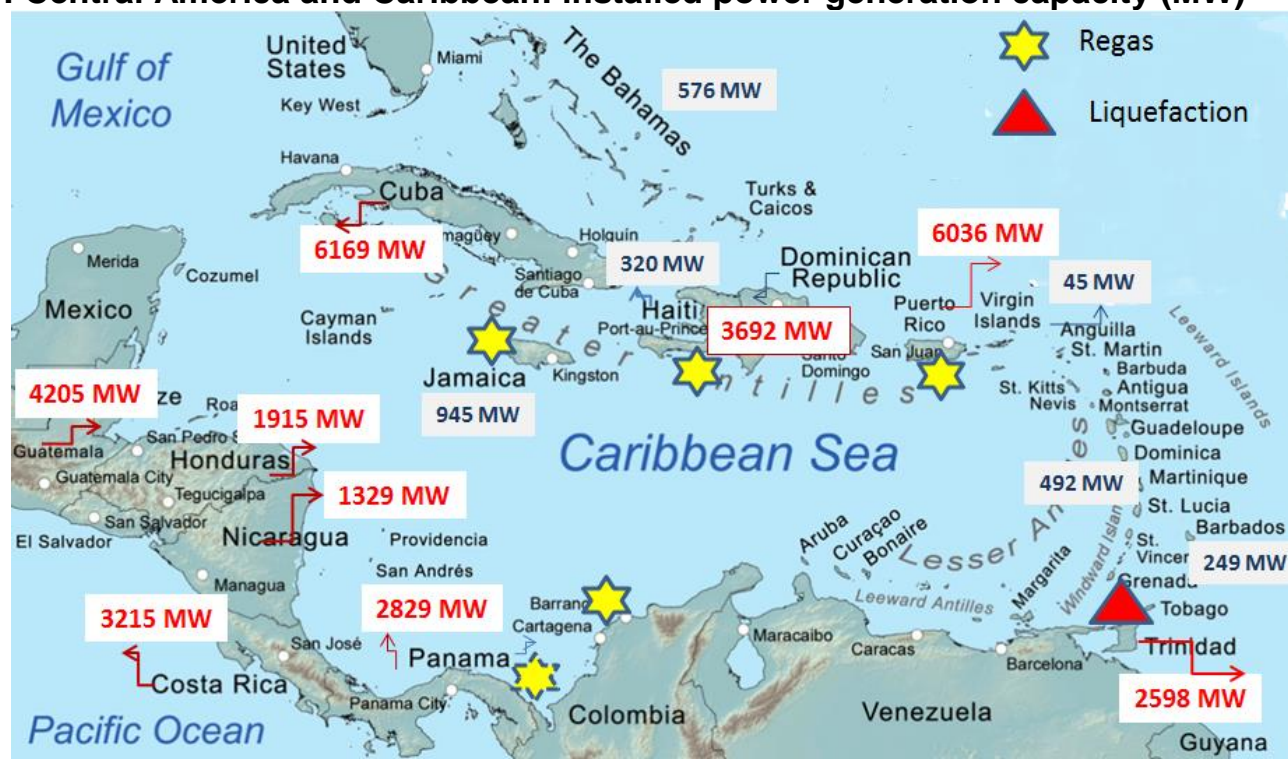

Source: (United Nations, 2014), (Ministerio de Energia y Minas - Guatemala, 2017)

\footnotetext{
${ }^{2}$ Except Cuba with a total installed capacity of $6.7 \mathrm{GW}$ and which is not covered in this study by lack of accurate data ${ }^{3}$ Barbados production in 2013: 55,000 $\mathrm{m}^{3} /$ day.

http://www.indexmundi.com/energy/?country=bb\&product=gas\&graph=production
} 

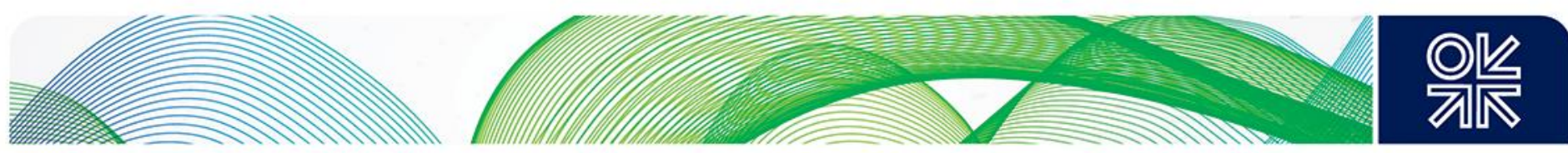

Most of the Caribbean Islands rely heavily on diesel and fuel oil for power generation, except for Trinidad \& Tobago, which uses natural gas extensively in the industrial and power sectors. Most Central American countries similarly rely on diesel and fuel oil although a few countries such as Guatemala, Costa Rica and Panama also have important hydro and biomass resources. The prevailing generation technology in most Caribbean countries consists of medium-speed/low-speed internal combustion engines running on diesel or heavyfuel oil (HFO)/bunker. These engines are very reliable and easy to maintain; however, they have low generation efficiency, typically $30 \%-40 \%$.

According to a study prepared for the Organisation of American States (OEA), the islands of Antigua \& Barbuda, The Bahamas, Dominica, Grenada, St. Kitts \& Nevis, St. Vincent and Grenadines are signatories to PetroCaribe, a program for purchasing oil from Venezuela with preferential payment conditions, such as low--interest loans for short-term financing. Each of the above nations individually enters a bilateral market agreement with the state oil company of Venezuela, Petróleo de Venezuela (PDVSA), with financing agreements extending for 25 years.

Table 1 and Appendix 2 show that, after deducting existing coal and gas fired capacity in Dominican Republic, Puerto Rico, Trinidad \& Tobago and Guatemala, the generation capacity theoretically replaceable with LNG in the region is $14.6 \mathrm{GW}$, of which $5.1 \mathrm{GW}$ is in Central America and $9.5 \mathrm{GW}$ in the Caribbean Islands ${ }^{4}$. This would require a maximum theoretical gas volume of $24.2 \mathrm{Bcma}$, of which 15.7 Bcma is in the Caribbean and 8.5 Bcma in Central America.

\begin{tabular}{|c|c|c|c|}
\hline Region & $\begin{array}{l}\text { Installed Capacity } \\
\text { (GW) }\end{array}$ & $\begin{array}{c}\text { Addressable } \\
\text { potential for gas } \\
\text { (GW) }\end{array}$ & $\begin{array}{c}\text { Potential gas/LNG } \\
\text { market (Bcma) }\end{array}$ \\
\hline $\begin{array}{l}\text { Caribbean } \\
\text { Islands }\end{array}$ & 15.1 & 9.5 & 15.7 \\
\hline Central America & 15.5 & 5.1 & 8.5 \\
\hline Total & 30.6 & 14.6 & 24.2 \\
\hline
\end{tabular}

Source: Authors' estimate based on (United Nations, 2014), (Ministerio de Energia y Minas - Guatemala, 2017)

It is worth noting that approximately $550 \mathrm{MW}$ of the addressable power capacity is located in countries where the maximum substitutable market is below $100 \mathrm{MW}$ and it would be very challenging to supply natural gas on an economic basis.

\section{Overview of potential and existing LNG markets \& projects}

\subsection{Dominican Republic}

\section{Economic and Energy Context}

The Dominican Republic (DR) is in the island of Hispaniola, which is shared with Haiti. As of July 2017, its population reached 10.7 million people ${ }^{5}$, of which approximately 3 million live in the metropolitan area of Santo Domingo, the capital city. The 2016 GDP was USD 72.8 billion at the official exchange rate, a GDP per capita of USD 6,722 and a GDP growth of $6.6 \%$ in 2016 . For decades the country has been an exporter of agricultural products such as sugar, coffee and tobacco, but it has since diversified to tourism, construction, free trade zones and gold mining.

The services sector accounted for $62 \%$ of the country's GDP in 2016. Dominican Republic is part of the CAFTA-DR, a free trade agreement dating from 2007 between the United States and a group of

\footnotetext{
${ }^{4}$ Cuba and Martinique are not included.

${ }^{5} \mathrm{https}: / /$ www.cia.gov/library/publications/the-world-factbook/geos/dr.html
} 

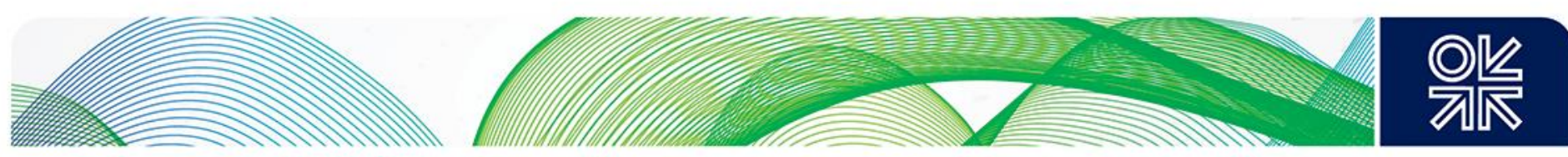

smaller countries in Central America: Costa Rica, El Salvador, Guatemala, Honduras, Nicaragua, and Dominican Republic. ${ }^{6}$ The US is the destination for half of DR's exports and remittances from the US accounts for approximately $7 \%$ of the country's GDP.

As of 2014 , total primary energy supply was 7.64 MTOE, of which nearly one quarter was destined to power generation. Electrification reached $98 \%$ of the population. The country has limited hydro resources; locally produced biofuels and waste account for around $10 \%$ of the primary energy supply and there is no indigenous production of natural gas, oil and coal. ${ }^{7}$

\section{Figure 2: Dominican Republic: key energy data (MTOE) - 2014}

\section{DR: Energy consumption by sector (2014)}

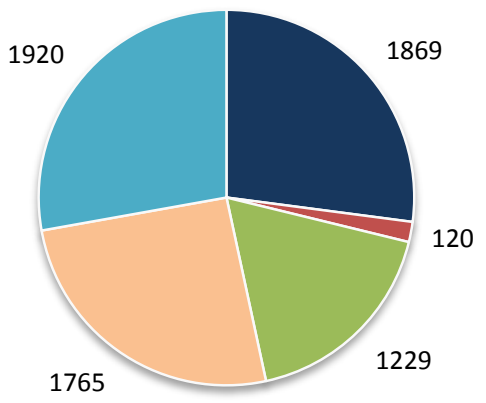

- Power $\square$ Refineries $=$ Industrial $=$ Transport $\approx$ Res/Com
DR: Power generation by fuel (2014)

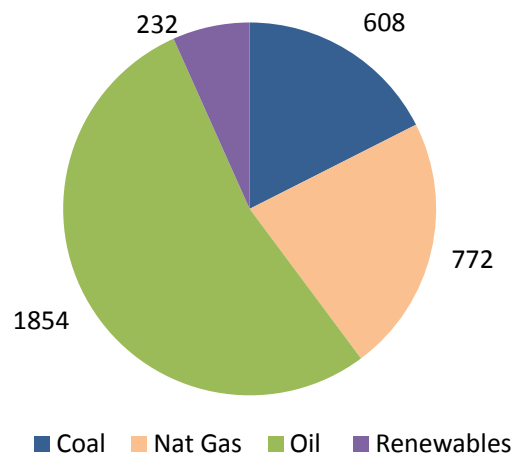

Source:

https://www.iea.org/statistics/statisticssearch/report/?year=2014\&country=DOMINICANR\&product=Balances

The structure of the power sector is a result of the reform process initiated in the 1990s, which resulted in the unbundling of the power sector and enabled the participation of the private sector in some activities. The Ministry of Energy and Mines (MEM) was formed in 2013, and is responsible for formulating and managing energy policies. The National Energy Commission (CNE) was established in 2001, with the task of energy policy development and national energy planning.

In 2016 the total installed capacity in the National Integrated Energy System (SENI) was $3.69 \mathrm{GW}$ with another $117 \mathrm{MW}$ added through the conversion to combined cycle of the AES DPP plant. The system is highly dependent on thermal power which accounted for circa $91 \%$ of the 15.9 GWh generated in 2016. 35\% of total generation uses Fuel Oil Fuel Oil No. 6, approximately 33\% natural gas, approximately 8\% Fuel Oil No. 2 and approximately 15\%. In 2016 hydraulic power represented $9.5 \%$ of energy generation and wind accounted for $2 \% 8$.

The electricity wholesale market is based on centralised economic dispatch. The centralised Coordinating Organisation $(\mathrm{OC})^{9}$ regulates planning and supervises the operation through the Centro de Control de Energía, which dispatches the system on real time using a cost-based merit order. Dispatches of electricity generation units are based on declared variable costs subject to audit by the OC. The hydroelectric generation units' variable cost is equal to zero, so these plants are always the first for dispatch. The last generation unit dispatched sets the spot price, on an hourly basis, which is always based on a fuel oil plant.

The SENI comprises 15 power generation companies, one of which is hydro, one transmission company - ETED (Empresa de Transmisión Eléctrica Dominicana) and three state-controlled distribution companies, Empresa Distribuidora de Electricidad del Sur (Edesur Dominicana), Empresa

\footnotetext{
${ }^{6}$ https://ustr.gov/trade-agreements/free-trade-agreements/cafta-dr-dominican-republic-central-america-fta

7 IEA: https://www.iea.org/statistics/statisticssearch/report/?year=2014\&country=DOMINICANR\&product=Balances

${ }^{8}$ https://www.one.gob.do/Estadisticas/227/energia-electrica

${ }^{9}$ Organismo Coordinador del Sistema Eléctrico Nacional Interconectado: http://www.oc.org.do
} 

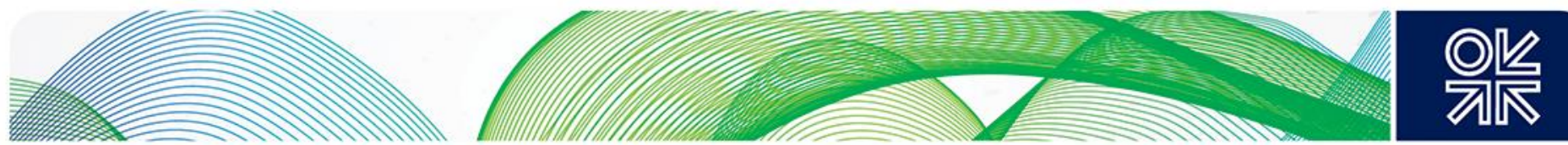

Distribuidora de Electricidad del Norte (Edenorte Dominicana) and Empresa Distribuidora de Electricidad del Este (Edeeste). The Corporación Dominicana de Empresas Eléctricas Estatales (CDEEE) is the agent for the wholesale market, which manages the energy contracts with the independent power producers connected to the SENI.

The distribution system is characterised by large technical and non-technical losses, which amounted to $33 \%$ in 2013 and a large amount of subsidies, which totalled USD 1.27 billion, equivalent to $2 \%$ of the country GDP in $2013^{10}$.

\section{LNG imports}

The Dominican Republic started receiving LNG in 2003 following the commissioning of the Andres LNG import terminal by AES. The shore-based terminal is located $30 \mathrm{~km}$ east of Santo Domingo; it was designed to receive cargoes of up to $145,000 \mathrm{~m}^{3}$, with a single storage tank of $160,000 \mathrm{~m}^{3} 11$ and supply a newly built $319 \mathrm{MW}$ power plant (Andres). In addition, the LNG terminal is connected to the AES-owned 236 MW Los Mina DPP power plant via a 34-km pipeline.

\section{Figure 3: Dominican Republic - AES Andres LNG terminal}

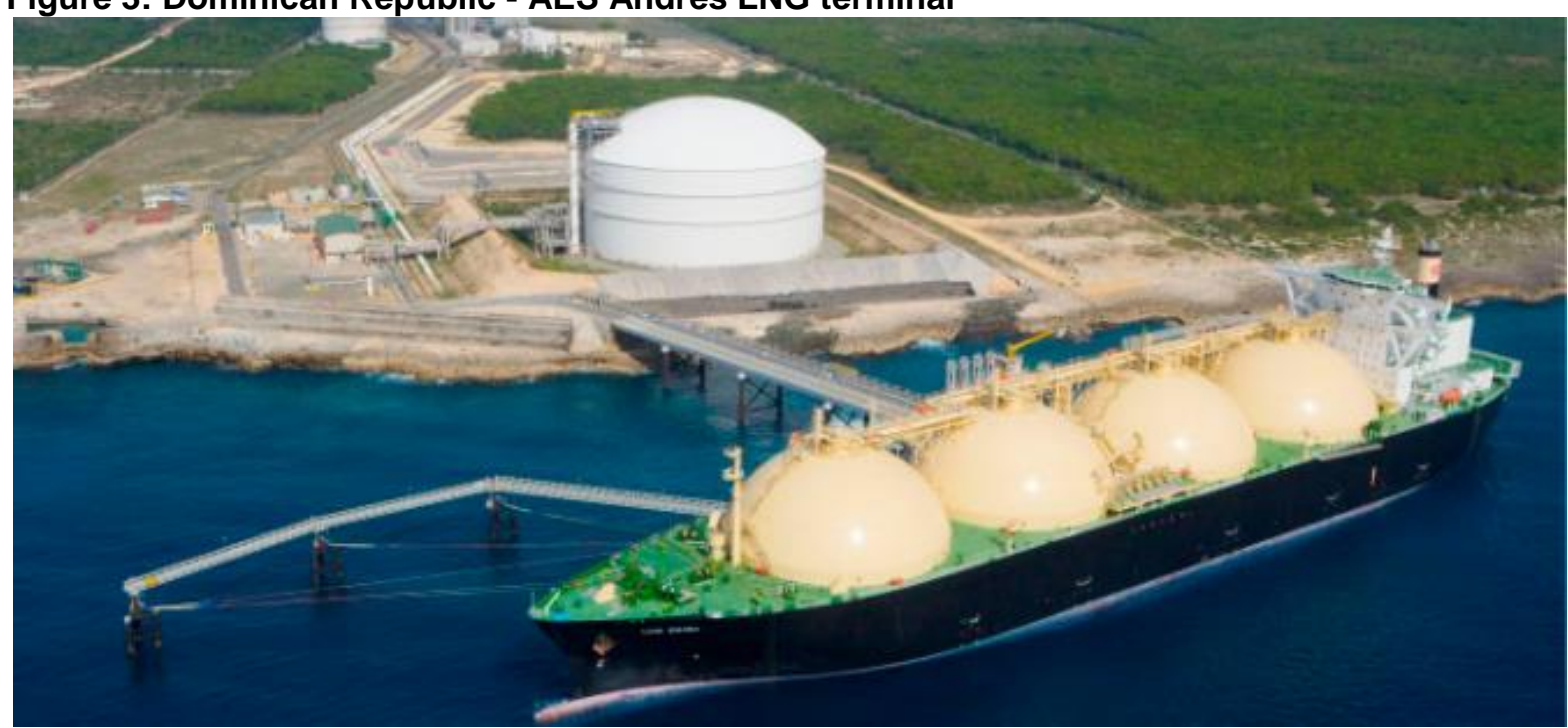

Source: http://aeslng.com/services/

Until 2010 the growth of LNG consumption in Dominican Republic was very slow, with AES achieving contract quantities only in 2011.

In 2016 the Dominican Republic imported 0.8 mtpa of LNG (1 Bcma), 8\% less than in $2015^{12}$. The fall in oil prices has encouraged the dispatch of less efficient oil-based power plants. Also in early 2017 AES added $114 \mathrm{MW}$ to Los Mina DPP power plant by converting the open cycle units into a combined cycle power plant, which increased the efficiency of the power plant, but will reduce gas consumption/MWh generated. AES is nevertheless projecting a total demand of up to $42-45 \mathrm{TBtu}$ for $2017^{13}$ (1.2 - $\left.1.3 \mathrm{Bcma}\right)$, according to Figure 4.

\footnotetext{
${ }^{10}$ (The Economist Intelligence Unit, 2015; The Economist Intelligence Unit, 2015)

${ }^{11}$ http://www.cbi.com/getattachment/ded83ebf-ff1a-462f-adf5-7f1dea3f163e/The-Dominican-Republic-LNG-Import-TerminalChalle.aspx

${ }^{12}$ GIIGNL: http://www.giignl.org/sites/default/files/PUBLIC_AREA/Publications/giignl_2017_report_0.pdf

13 (Bolinaga, 2017)
} 

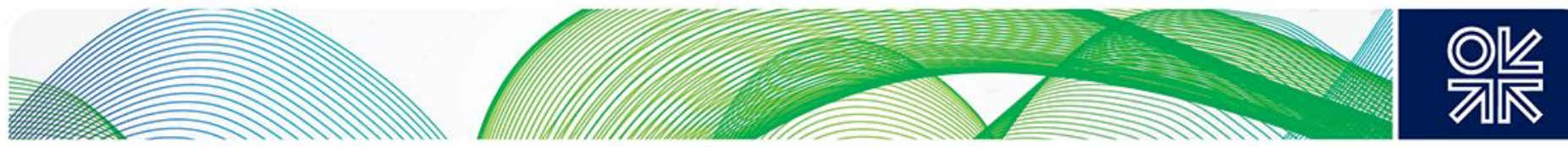

Figure 4: Evolution of LNG consumption in the Dominican Republic

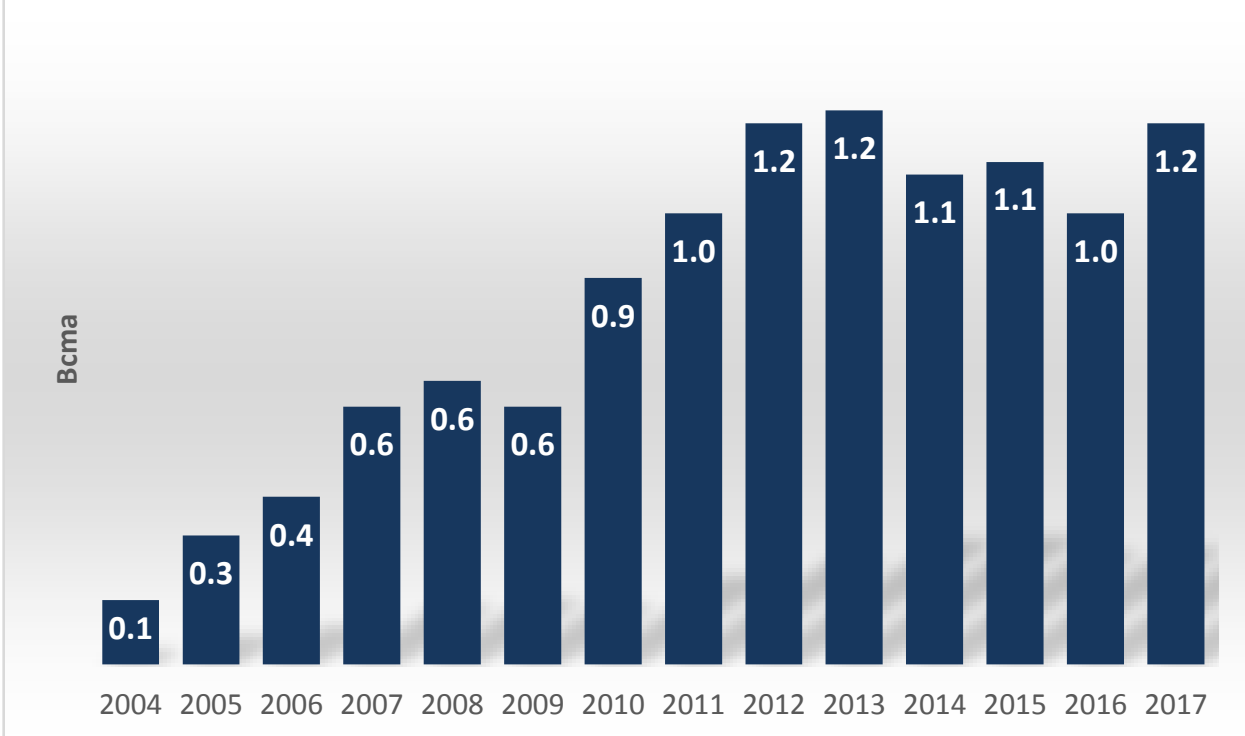

Source: Adapted from (Bolinaga, 2017)

\section{Outline Commercial Structure}

In 2001 an AES subsidiary entered a 20-year, 1 Bcma (33 TBtu/year), Henry Hub indexed, LNG supply deal with BP Amoco (subsequently BP Gas Marketing Ltd.), containing a commercial innovation, the so called "branded LNG", whereby the supply was not guaranteed by a single nominated production source but by the supplier LNG portfolio. ${ }^{14}$ This commercial innovation in 2001 is nowadays very commonplace in the LNG trade. The contract became effective in 2003. The AES subsidiary then sells LNG to the AES owned Andres and DPP power plants, charging a USD $15,000 /$ month fixed fee plus a variable fee of USD 1.2/MMBtu on top of the LNG purchase price ${ }^{15}$.

In 2005 AES entered into a 1-year supply agreement with a local retailer, Linea Clave, which procured LNG at the Andres terminal to supply industrial consumers by truck ${ }^{16}$ and subsequently AES executed additional gas supply deals with other smaller power producers.

The gas and LNG supply contracts are denominated in U.S. dollars with an average initial duration of three years. The LNG purchase price is passed through to AES consumers who also pay fees adjusted annually by U.S. CPI for the use of Andres' services, depending on the point of delivery of the natural gas (a Terminal Fee, a Truck Loading Terminal Fee and a Transportation Fee).

AES LNG is committed to pay BP nearly USD $1 \mathrm{Bn}$ for the contractual amounts due for delivery until 2023, based on NYMEX (Henry Hub) as of 31 March 2017 (USD 3.13/MMBtu), as summarised in Table $2^{17}$. Both Andres and DPP power plants have PPAs with the distribution company EDE-Este, which are also indexed to Henry Hub therefore the changes in LNG prices are passed on to the ultimate off-taker.

\footnotetext{
${ }^{14} \mathrm{http}: / /$ www.gasandoil.com/news/ms america/be7dfc213a41b694206965d1251d4385

${ }^{15} \mathrm{http}: / /$ aesmcac.com/aesdominicana/wp-content/uploads/2017/03/AES-Andres-BV-Estados-Financieros-Interinos-1Q-2016Norma-USGAAP.pdf

${ }^{16} \mathrm{http}: / /$ aesmcac.com/aesdominicana/wp-content/uploads/2017/07/FS-ANDRES-USGAAP-1Q-2017-Unaudited.pdf $1717 \mathrm{http}: / /$ aesmcac.com/aesdominicana/wp-content/uploads/2017/03/AES-Andres-BV-Estados-Financieros-Interinos-1Q-2016Norma-USGAAP.pdf
} 

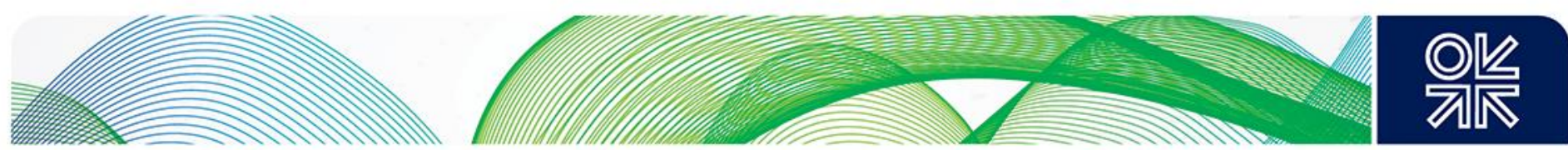

Table 2: Dominican Republic: AES LNG payment commitment

\begin{tabular}{|l|l|}
\hline Year & Payment commitment (USD million) \\
\hline $\mathbf{2 0 1 7}$ & 118.4 \\
\hline $\mathbf{2 0 1 8}$ & 159.4 \\
\hline $\mathbf{2 0 1 9}$ & 153.3 \\
\hline $\mathbf{2 0 2 0}$ & 145.6 \\
\hline $\mathbf{2 0 2 1}$ & 154.1 \\
\hline $\mathbf{2 0 2 2}$ and thereafter & 194.7 \\
\hline Total & 925.5 \\
\hline
\end{tabular}

Source: http://aesmcac.com/aesdominicana/wp-content/uploads/2017/07/FS-ANDRES-USGAAP-1Q-2017Unaudited.pdf

\section{Future developments and evolving business models}

The market for natural gas in the Dominican Republic consists of small industries and hotels scattered in the north coast, therefore it was not viable to build gas infrastructure downstream of the LNG terminal. This has prompted the development of new business models for natural gas via "virtual pipelines" of trucked LNG. In addition to directly supplying its two power plants, in 2009 AES installed two truck-loading bays at the Andres terminal, each one capable of supplying two trucks/hour. There are currently six LNG distribution companies which supply commercial, industrial and automotive customers. As of 2016 the natural gas market consisted of 65 industrial users, 7 power plants, 32 CNG stations and 15,000 vehicles.

In 2015 AES started to reconfigure the Andres terminal to allow for LNG re-loads onto ships of 10,000-60,000 cubic metres LNG capacity. AES plans to turn the terminal into an LNG trans-shipment and bunkering hub for the Caribbean, Central and South America. The first re-load operation took place in February 2017. According to AES, circa 60,000 and 70,000 cubic metres of LNG was reloaded from the Andres terminal on to the $138,826 \mathrm{~cm}$ capacity Cadiz Knutsen on February 11 $2017^{18}$. AES is also offering to supply LNG to smaller markets via ISO certified cryogenic containers as well as use their terminals in the Dominican Republic and Panama to develop a "hub and spoke" business model, serving the Caribbean and Central America.

AES Andres is also considering the construction of a second LNG storage tank to allow supplying an additional $300 \mathrm{MW}$ of generation capacity.

\section{Other proposed LNG projects, residual demand and growth}

Antillean Gas, Ltd is a consortium formed in 2013 by local companies Propagas, Tropigas, Vicini and InterEnergy, together with Colombian gas distribution company Promigas and international companies Ipson and BW Group ${ }^{19}$. The latter would be responsible for supplying a floating regasification unit to the project. The consortium planned to build an LNG terminal at San Pedro de Macoris, in the eastern region, anchored by approximately 1,000 MW of existing power plants, but the project has not made significant progress since 2015. This is due to a combination of the restructuring of the companies in the consortium, reduced attractiveness of LNG vis-a-vis lower oil prices, and delays in negotiating underpinning PPAs with the government-owned power distribution companies. In addition, the construction of $770 \mathrm{MW}$ of coal-fired power plant (Punta Catalina), has posed further challenges for the development of additional gas-fired capacity in the island. The commissioning of the coal plant is expected to take place in two phases, in 2019 (phase 1) and 2020 (phase 2).

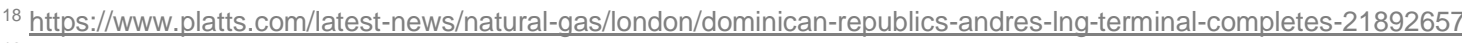

19 (Lluberes, 2015)
} 

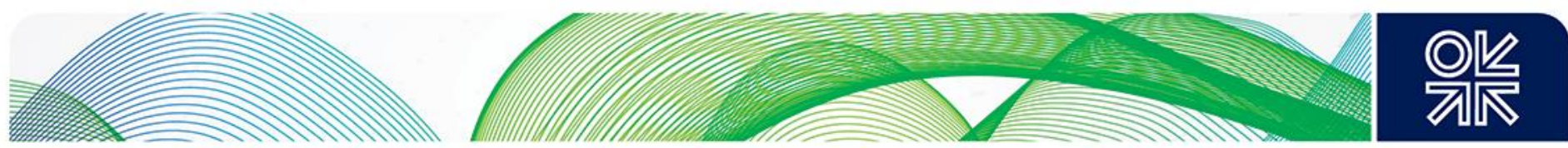

\subsection{Puerto Rico}

\section{Economic and Energy Context}

The population of Puerto Rico is currently estimated at around 3.4 million, having fallen from 3.8 million in 200020. GDP per capita in 2013 was estimated at USD 28,700 - up from around USD 16,000 in $2000^{21}$, but real GDP growth has been negative every year since 2006 . The decline in the economy and the corresponding population decline have been attributed to the removal of tax incentives for investment, and the higher incomes available in mainland US ${ }^{22}$. GDP composition is split roughly 50:50 between industry and services (predominantly tourism and financial services), with agriculture just $0.8 \%$ of GDP23.

About $80 \%$ of energy used in Puerto Rico comes from petroleum. The last refinery closed in 2009 , and all petroleum products are now imported. 24

Figure 5: Generation mix, Puerto Rico, 2015

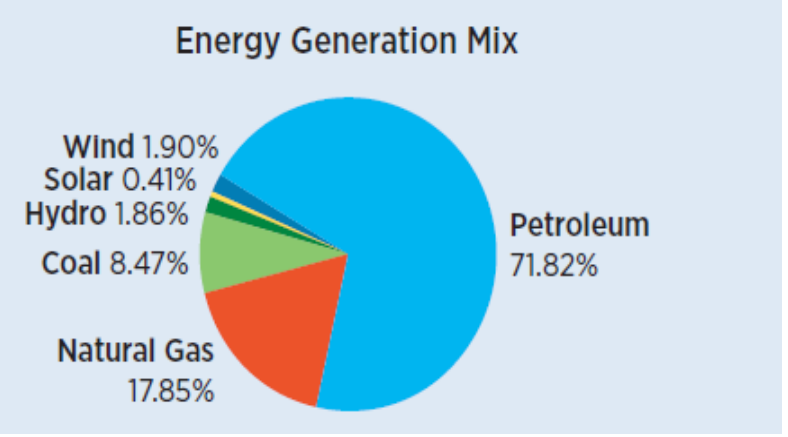

Source: Energy Transition Initiative, Puerto Rico Snapshot, 2015. https://www.nrel.gov/docs/fy15osti/62708.pdf

Total installed electricity generating capacity is around $6,000 \mathrm{MW}$, with total generation of around $19.4 \mathrm{TWh}$, of which (as shown in Figure 5) $72 \%$ was derived from petroleum, $18 \%$ from natural gas and $8 \%$ from coal ${ }^{25}$. Most of the generation capacity is oil-fired, and mostly owned and operated by Puerto Rico Electric Power Authority (PREPA), apart from a 450MW coal plant operated by AES and a $510 \mathrm{MW}$ gas-fired plant operated by EcoElectrica.

\section{History of LNG import and future plans}

Puerto Rico's first LNG import terminal in Peñuelas, in the south of the island came into operation in 2000. The combined import terminal and power plant project, initially led by Enron International, achieved financial close in December 1997, with an estimated cost of USD 670million. ${ }^{26}$ In 2012, EcoElectrica expanded the regasification capacity to supply fuel to two nominal $400-\mathrm{MW}$ conventional steam units at PREPA's Costa Sur Power Plant. This plant was retrofitted for dual fuel operation in 2011. ${ }^{27}$ The terminal imported 1.25 million tonnes of LNG in 2016. ${ }^{28}$

Plans for a second LNG import terminal in Puerto Rico have been under discussion from as early as 2008, but have not yet reached an investment decision. The Aguirre Gasport, which would be located about 40 miles east of Peñuelas, on the south coast of the island, is being developed by Excelerate

\footnotetext{
${ }^{20}$ World Bank (http://data.worldbank.org/country/puerto-rico )

${ }^{21}$ World Bank (http://data.worldbank.org/country/puerto-rico )

${ }^{22}$ CIA World Factbook: Puerto Rico Economy. https://www.cia.gov/library/publications/the-world-factbook/geos/rq.html

${ }^{23}$ CIA World Factbook: Puerto Rico Economy.

${ }^{24}$ US EIA: Puerto Rico Energy Profile https://www.eia.gov/state/?sid=RQ

${ }^{25}$ Energy Transition Initiative, Puerto Rico Snapshot, 2015. https://www.nrel.gov/docs/fy15osti/62708.pdf

${ }^{26}$ Oil and Gas Journal, $23^{\text {rd }}$ Feb 1998

${ }^{27}$ FERC Feb 2015: Aguirre Offshore GasPort Final Environmental Impact Statement

https://energy.gov/sites/prod/files/2015/02/f20/EIS-0511-FEIS-Volume1-2015.pdf

${ }^{28}$ GIIGNL Annual Report 2017. http://www.giignl.org/sites/default/files/PUBLIC AREA/Publications/giignl 2017 report 0.pdf
} 

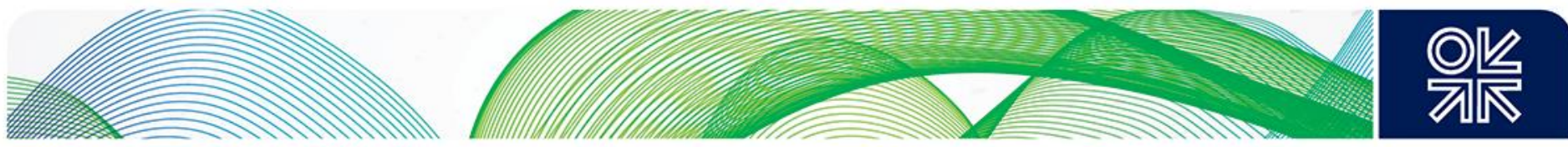

Energy, one of the leading providers of floating storage and regasification (FSRU) systems. In November 2010, PREPA conducted an expression of interest / pre-qualification survey for a project to import natural gas and convert the $1500 \mathrm{MW}$ oil-fired Aguirre power station to gas-firing. ${ }^{29} \mathrm{~A}$ formal application to the US Federal Energy Regulatory Commission (FERC) was filed in April 2013, and the Environmental Impact Statement was approved in July 2015.30 The project continued to make slow progress, and in August 2017, Excelerate cancelled its contracts with PREPA as a result of the utility filing for bankruptcy.

Thus it is at present unclear whether the second terminal will proceed. It is also possible that an alternative plan to build a gas pipeline from the existing Peñuelas LNG import terminal to the Aguirre power plant will be re-evaluated. ${ }^{31}$ Hurricanes Irma, Jose and Maria caused substantial damage to the power transmission infrastructure in Puerto Rico, from which the island has been taking a considerable time to recover.

\section{LNG import physical arrangement}

The Peñuelas LNG import terminal has a single storage tank with a capacity of $160,000 \mathrm{~m}^{3}$ and supplies an adjacent $500 \mathrm{MW}$ combined cycle power plant. Both the terminal and the power plant are operated by EcoEléctrica, $47.5 \%$ owned by Gas Natural Fenosa. ${ }^{32}$ The terminal was originally built with two vaporisers each with a capacity of $93 \mathrm{MMscf} / \mathrm{day}$, and in 2012 a further two vaporisers of the same size were added. ${ }^{33}$ Total authorised send out was $186 \mathrm{MMscf} / \mathrm{d}$, with two of the vaporisers as spares, until FERC approval in August 2017 to increase send out to $279 \mathrm{MMscf} / \mathrm{d} .{ }^{34}$

Figure 6: Puerto Rico: Peñuelas LNG import terminal in 2012

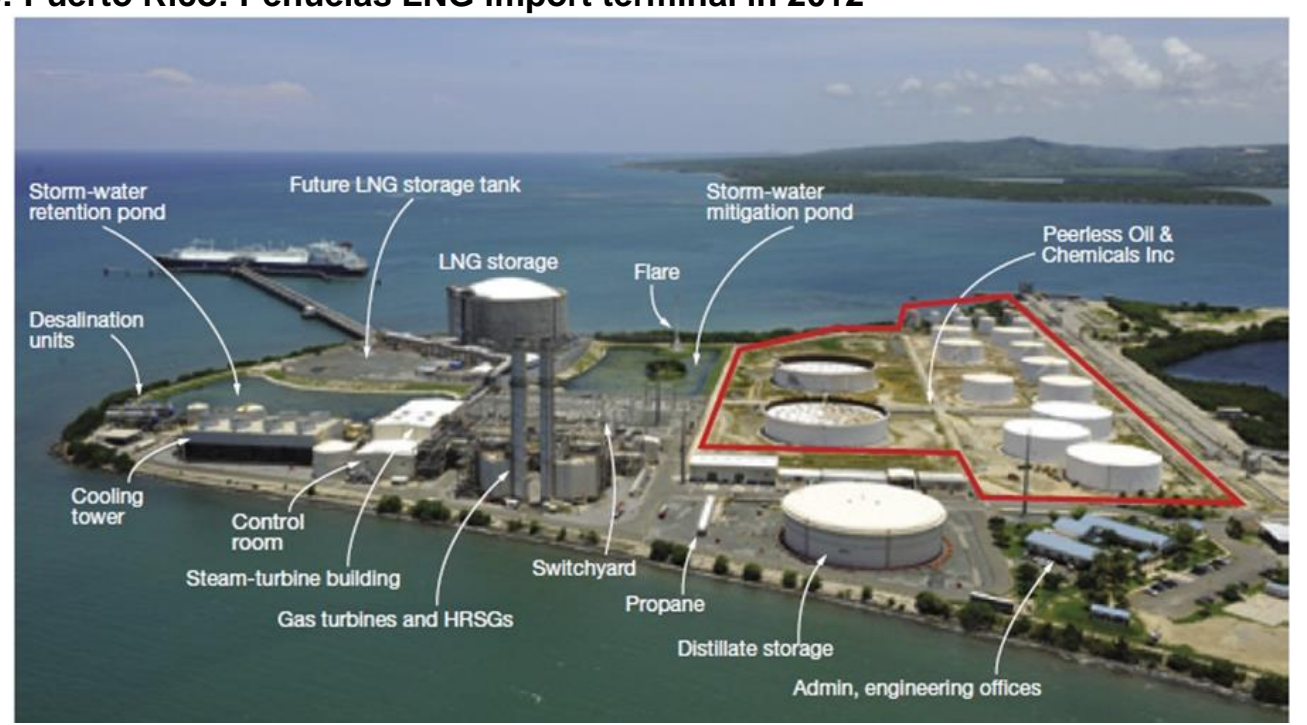

Source: Combined Cycle Journal, Q4 2012 http://www.ccj-online.com/4q-2012/plant-reports-ecoelectrica-Ip/

Consideration has been given to constructing natural gas pipelines. Figure 7 shows routes of the proposed pipelines from the Peñuelas terminal to other power plants in Puerto Rico. ${ }^{35}$ Construction of the 42-mile long (68km) Gasoducto del Sur pipeline began in 2008, but only $10 \mathrm{~km}$ were constructed

\footnotetext{
${ }^{29}$ Aguirre Gasport presentation to Caribbean Energy Conference, January 2013 https://energy.gov/sites/prod/files/2015/02/f20/EIS-0511-FEIS-Volume1-2015.pdf

${ }^{30}$ http://en.aguirreoffshoregasport.com/the-aguirre-offshore-gasport-project-overview/gasport-project-status-and-timeline/

31 http://caribbeanbusiness.com/prepa-lacks-financing-for-natural-gas-projects/

32 Gas Natural Fenosa company information

${ }^{33}$ FERC Docket No CP13-516-000, June 2014 https://www.ferc.gov/whats-new/comm-meet/2014/061914/C-3.pdf

${ }^{34}$ FERC Docket No CP16-492-000, August 2017 https://www.ferc.gov/CalendarFiles/20170824163443-CP16-492-000.pdf

${ }^{35}$ FERC Aguirre Offshore Gasport Environmental Impact statement, Feb 2015

https://energy.gov/sites/prod/files/2015/02/f20/EIS-0511-FEIS-Volume1-2015.pdf
} 

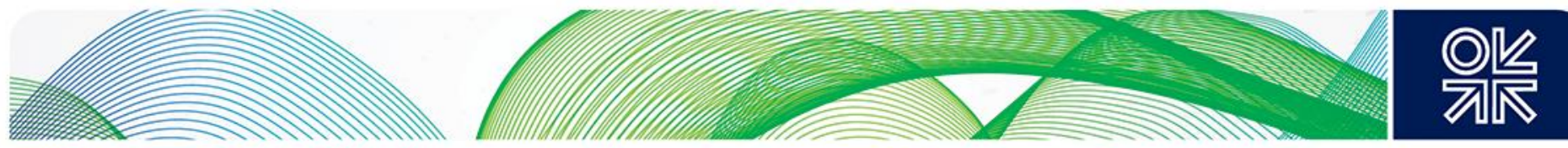

before the project was cancelled on account of public opposition in 2009. There continues to be a discussion regarding the relative merits of the Aguirre Offshore Gas Port or the pipeline. ${ }^{36}$

\section{Figure 7: Puerto Rico- Proposed Natural Gas pipelines}

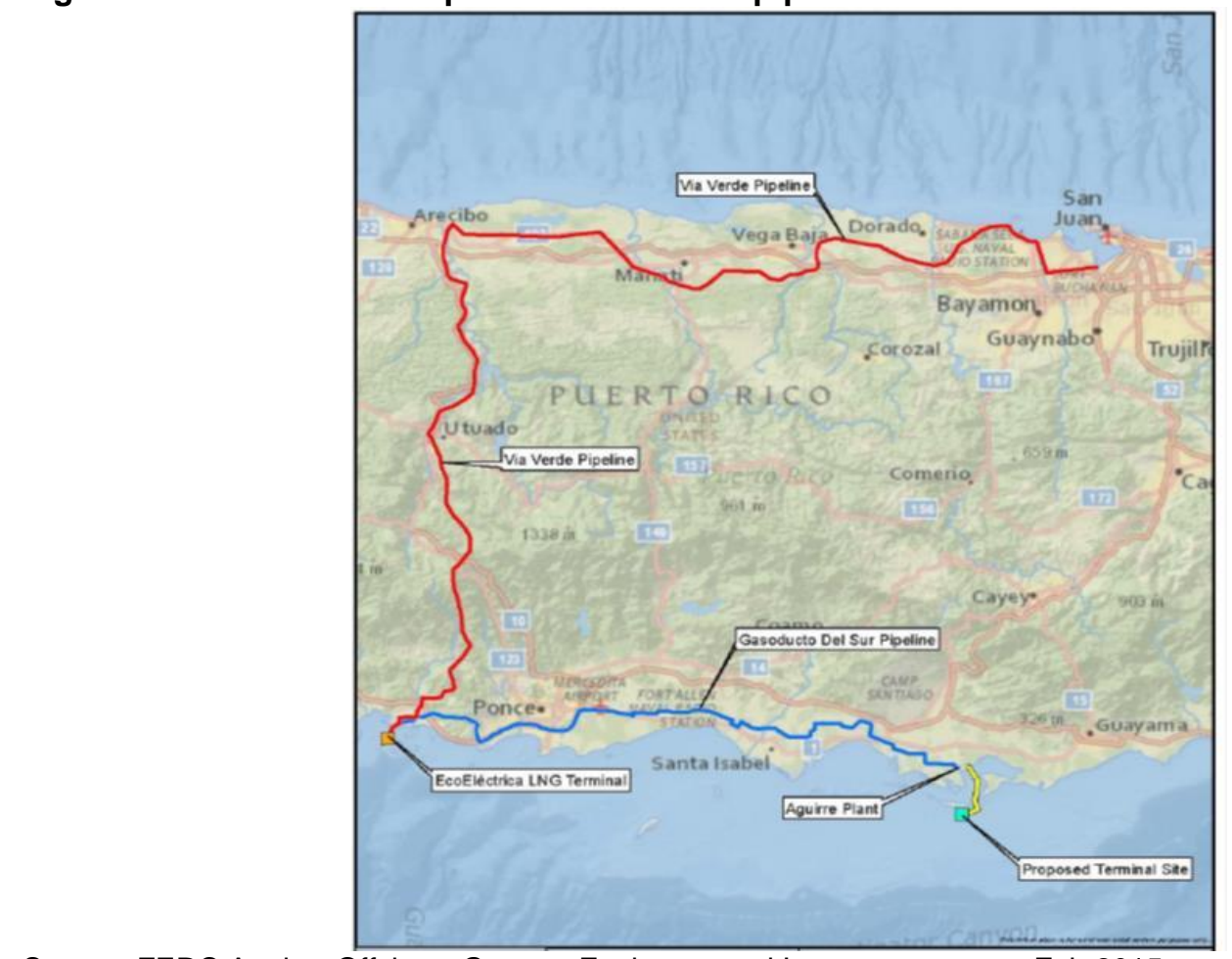

Source: FERC Aguirre Offshore Gasport Environmental Impact statement, Feb 2015

\section{Outline Commercial Structure}

The Peñuelas terminal and power plant is an integrated facility, owned and operated by Ecoeléctrica. There is a 22-year power purchase and operations agreement between Ecoeléctrica and PREPA, under which PREPA contracts for LNG directly, and Ecoeléctrica is paid a tolling fee for LNG handling, storage, regasification and deliver of gas to Costa Sur. ${ }^{37}$ As part of Gas Natural Fenosa's acquisition of the Ecoeléctrica project in 2003, it obtained a Tolling Services Agreement giving it the exclusive rights to all the excess capacity at the terminal as well as the rights to add more capacity to the facility. ${ }^{38}$

\section{Development plans and future potential}

In June 2014, FERC granted approval for Ecoeléctrica to supply LNG to a truck loading facility, which Gas Natural Fenosa (GNF) was proposing to construct on land adjacent to the Peñuelas terminal. ${ }^{39}$ In a subsequent presentation in October 2015, GNF gave further details of its plans to construct the truck loading facility and distribute natural gas to residences and commerce. ${ }^{40}$

To date, the truck loading facility has not been completed, but instead Crowley, a US logistics company is supplying LNG in ISO-containers to industrial customers in Puerto Rico. In September 2014, the first load of LNG was delivered to the Coca Cola bottling plant in Cidra, having converted the plant to run on natural gas rather than diesel, as well as using the low temperature LNG to reduce

\footnotetext{
${ }^{36} \mathrm{http}$ ://caribbeanbusiness.com/puerto-rico-govt-pushes-for-prepas-rsa-deal-awaits-for-boards-approval/ June 2017

37 http://www.ccj-online.com/4q-2012/plant-reports-ecoelectrica-lp/

38 http://logicenergyusa.com/presentations/TLF\%20-\%20Logistic\%20October\%202015.pdf , Oct 2015

${ }_{39}$ FERC Docket No: CP13-516-000, June 2014 https://www.ferc.gov/whats-new/comm-meet/2014/061914/C-3.pdf

${ }^{40}$ http://logicenergyusa.com/presentations/TLF\%20-\%20Logistic\%200ctober\%202015.pdf
} 

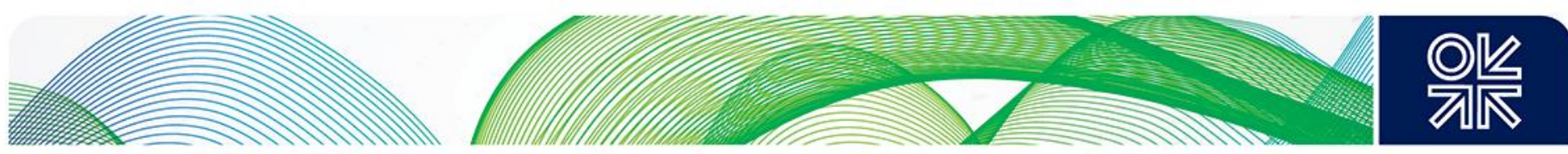

the demand for refrigeration. ${ }^{41}$ Crowley also supplies LNG to other customers in Puerto Rico, including Coca Cola's Cayey plant, the cereal mill operated by Molinos de Puerto Rico and a major pharmaceutical company. ${ }^{42}$

As discussed above, there are competing proposals for supply of natural gas to the Aguirre power plant: at this stage it is unclear whether either or neither of the Gasoducto del Sur pipeline or the Aguirre Offshore Gas Port will go ahead.

\subsection{Jamaica}

\section{Economic and Energy Context}

Jamaica is a country of nearly 3 million people ${ }^{43}$ growing at less than $0.5 \% / y e a r$. GDP per capita is just under USD 5,000 ${ }^{44}$, having been fairly stable around this level since the mid-1990s. Jamaica was once a major sugar exporter, but now imports sugar and services account for more than $70 \%$ of GDP ${ }^{45} .30 \%$ of GDP is estimated to be derived from tourism. ${ }^{46}$ In the early 1970 s, Jamaica was the leading bauxite producer in the world, although in 2016 it exported only 5.6 million tonnes, or around $7 \%$ of global bauxite production.

Primary Energy supply in 2014 totalled 3.2 mtoe, down from 4.6 mtoe in 2007 before the closure of several bauxite/alumina plants in the wake of the global financial crisis. $2.6 \mathrm{mtoe}(81 \%)$ of primary energy supply in 2014 was from crude oil and oil product imports (4.1 mtoe or $91 \%$ in 2007) ${ }^{47}$. The Government of Jamaica has developed a strategy to diversify its energy supply in order to improve its international competitiveness and reduce its dependence on imported petroleum. ${ }^{48}$

Figure 8: Jamaica: Energy Consumption and Production (2015)

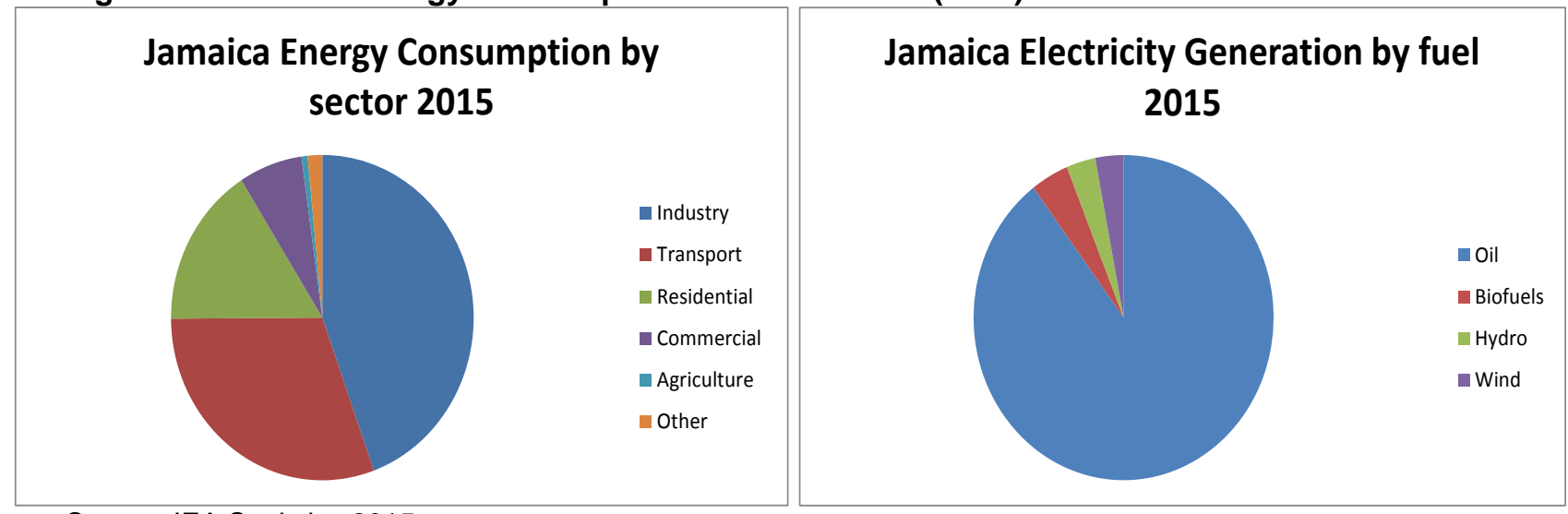

Source: IEA Statistics 2015

(https://www.iea.org/statistics/statisticssearch/report/?country=Jamaica\&product=balances)

Total electricity generation in 2016 was 4.35 TWh, an increase of $3.7 \%$ from $2015.6 \%$ of generation was from hydropower, with the remainder being from oil-fired power plants. ${ }^{49}$ Total installed capacity

\footnotetext{
${ }^{41} \mathrm{http}: / /$ www.crowley.com/content/download/26693/202269/version/3/file/LNG-Story.pdf

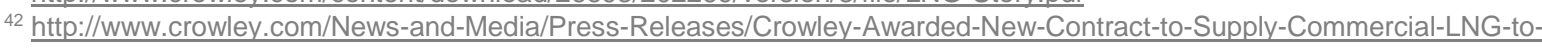
Molinos-de-Puerto-Rico

${ }^{43}$ ClA World Factbook: July 2016 estimate 2.97 million

${ }^{44}$ Trading Economics, based on World Bank 2016: USD 4796. https://tradingeconomics.com/jamaica/indicators

${ }^{45} 2017$ Index of Economic Freedom http://www.heritage.org/index/country/jamaica

${ }^{46} \mathrm{ClA}$ World Factbook

${ }^{47}$ All data from IEA Sankey diagrams.

${ }^{48}$ Govt. of Jamaica, Bidding document for LNG, August 2011, p8 http://www.cabinet.gov.jm/files/docs/procurement/RFP-2011L002-LNG-Floating-Storage-Regas-Terminal-AMENDED-15-Sept-2011.pdf

${ }^{49}$ Economic and Social Survey Jamaica 2016, Planning Institute of Jamaica.

https://webstore.pioj.gov.jm/reportyear.aspx?Sectionld=4
} 

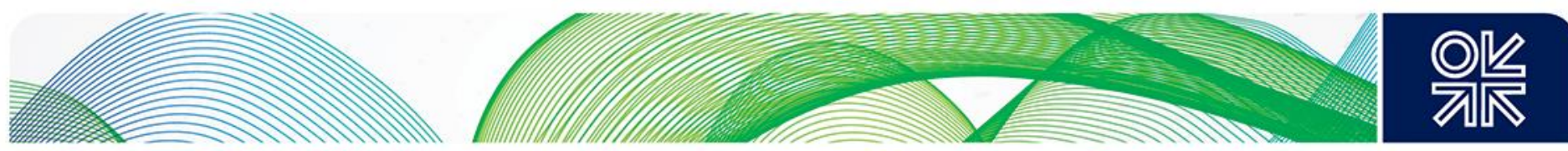

was 923MW, of which 634MW was operated by Jamaica Public Service (JPS), the utility also responsible for transmission and distribution of electricity across the island, and 289MW from Independent Power Producers. ${ }^{50}$ At end 2015, only $1.4 \mathrm{MW}$ of photo-voltaic systems were connected to the grid, but this was planned to increase to nearly $70 \mathrm{MW}$ by end $2017 .{ }^{51}$

\section{History of plans to import LNG}

Jamaica was considering imports of LNG as early as 2004 when an agreement was signed with Trinidad and Tobago for LNG supply of $1.1 \mathrm{mtpa}$ for 20 years starting in 2009 for use in the Jamalco bauxite refinery and the Jamaica Public Service (JPS) power plants. ${ }^{22}$ Subsequently, Trinidad informed Jamaica that it did not have sufficient gas supply, and in 2007 Jamaica's then Prime Minister Portia Simpson Miller signed a memorandum of understanding with Venezuela's President Hugo Chavez. This contemplated that Venezuela would start supply of LNG to Jamaica by 2009. ${ }^{53}$ When these plans did not progress, the Government issued tenders for LNG Infrastructure and LNG Supply in June 2011. Through 2012 and 2013, it was decided that LNG would be too expensive an option given the relatively small demand. In 2013, the Government withdrew its support for LNG and expressed support for coal as an alternative energy source. ${ }^{54}$ Finally, in November 2015, the power utility, JPS, signed an agreement with New Fortress Energy (NFE), a subsidiary of US-based Fortress Investment Group, for supply of gas to the 120MW Bogue power plant. Following this agreement, the infrastructure was completed remarkably quickly and first gas was supplied to the power plant by end $2016 .{ }^{55}$

\section{Figure 9: Jamaica LNG infrastructure}

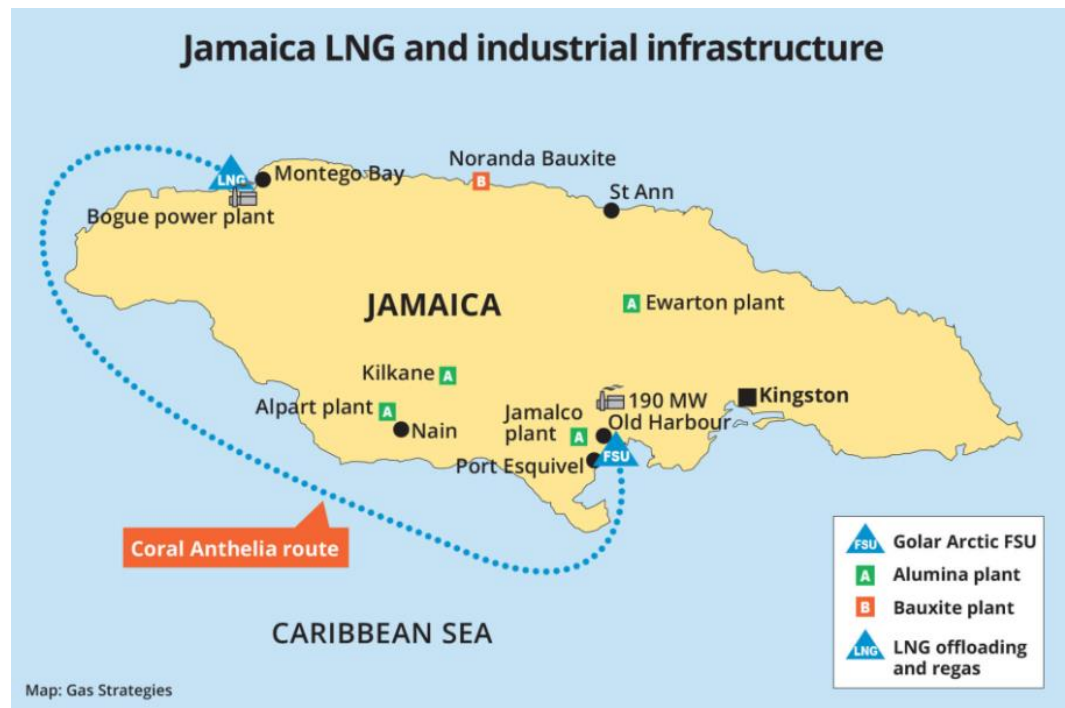

Source: Gas Strategies blog http://www.gasstrategies.com/blogs/blazing-trail-caribbean

\section{LNG import physical arrangement}

The physical supply chain set up by NFE is relatively unusual in the LNG industry. Initially, NFE had considered supply by ISO-containers by road and container ship from its existing facility in Florida, but the logistics and risks of this were ultimately considered unsuitable, so the current alternative scheme

\footnotetext{
${ }^{50}$ Energy Transition Initiative, Energy Snapshot Jamaica http://www.nrel.gov/docs/fy15osti/63945.pdf

${ }^{51}$ https://www.pv-magazine.com/2017/04/28/jamaica-targets-300-million-renewable-energy-investments/

52 Reuters, 24 June 2009 http://www.reuters.com/article/trinidad-jamaica-Ing-idUSN6053840120090624

${ }^{53}$ Oil\&Gas Journal 13 March 2007 http://www.ogj.com/articles/2007/03/venezuela-signs-mou-for-Ing-supply-to-jamaica.html

54 Jamaica Sustainable Energy Roadmap, Worldwatch Institute, Oct 2013 http://www.worldwatch.org/system/files/Jamaica-

Sustainable-Energy-Roadmap-112013.pdf

55 http://jis.gov.jm/Ing-arrives-jps-bogue-power-plant/
} 

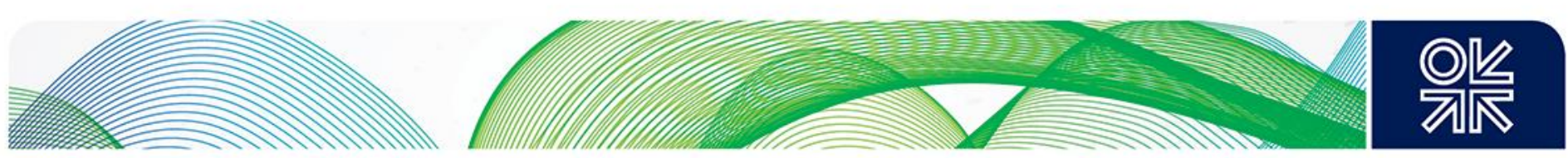

was adopted. ${ }^{56}$ A chartered LNG vessel, Golar Arctic $\left(138,000 \mathrm{~m}^{3}\right)$ serves as a floating storage unit (FSU), moored in a sheltered bay on the south side of Jamaica. It arrived in August 2016 with an initial cargo loaded in Nigeria, and a second cargo was delivered by ship to ship transfer from Trinidad in February 2017. ${ }^{57}$

NFE has also chartered the smaller LNG vessel, Coral Anthelia $\left(6,500 \mathrm{~m}^{3}\right)$ as a shuttle tanker. Approximately once a week, this vessel lifts a cargo from the FSU, and delivers it to an LNG receiving terminal (storage approximately $7,000 \mathrm{~m}^{3}$ ) at Montego Bay on the NW coast of the island. The LNG is vaporised in the Montego Bay terminal and the gas delivered by pipeline (approx. $2 \mathrm{~km}$ length) to the Bogue Power plant.

The Bogue plant, a $120 \mathrm{MW}$ combined cycle gas turbine facility, had been operating entirely on diesel since it was commissioned in 2003, and was converted by JPS to dual fuel, LNG and diesel. 58

\section{Outline Commercial Structure}

A gas supply agreement between NFE and JPS was signed in August 2015. Under this agreement, NFE assumed responsibility for delivering gas to the burner tip, while JPS was responsible for converting the Bogue power plant to run on gas. ${ }^{59}$ Thus NFE is responsible for LNG procurement and for putting the infrastructure in place (as described above). A 3-year deal has been signed by NFE and Centrica for supply of LNG. ${ }^{60}$

The commercial terms of these deals have not been disclosed, but speaking to the Jamaica Observer in August 2016, the CFO of JPS said that the price was based on the Henry Hub index plus an agreed margin, and that he expected the price in September 2016 to be slightly cheaper than the cost of the oil alternative..$^{61}$ On the other hand, an article in the Jamaica Gleaner in February 2016 claimed that the delivered cost of gas would be twice the price of fuel oil and add between USD 25 and 45 million to the cost of fuel. ${ }^{62}$ Both agreed, however, that the gas price was likely to be less volatile than the oil price.

\section{Development plans and future potential}

In a separate transaction, the South Jamaica Power Company, a subsidiary of JPS has started construction of a $190 \mathrm{MW}$ power plant in Old Harbour Bay (see map above). Gas will also be supplied by NFE and the power sold to JPS under a long-term power purchase agreement. This project reached financial close in March 2017.63 To deliver the gas, NFE will construct a berth and regasification facility, approximate $5 \mathrm{~km}$ offshore to the south of the power plant. The floating storage unit (currently anchored in the bay) will be moored at the berth, the LNG regasified on the offshore platform, and the gas transmitted by 16 " pipeline to the power plant. ${ }^{64}$

Expanding demand for LNG further, two industrial users, the bauxite company, Jamalco, and the Red Stripe brewery, are also reported to have signed deals with NFE to switch their fuel sourcing from oil to gas. ${ }^{65}$

\footnotetext{
${ }^{56}$ Power Engineering 14 Sept 2015: Risk Review leads to Alternative Plan for Jamaica Fuel Conversion http://www.powereng.com/articles/print/volume-119/issue-9/features/risk-review-leads-to-alternative-plan-for-jamaica-fuel-conversion.html ${ }^{57}$ https://www.icis.com/resources/news/2017/02/23/10081759/corrected-centrica-wins-three-year-Ing-supply-deal-to-jamaica/ $58 \mathrm{http}: / /$ iis.gov.jm/ips-launches-2-5-billion-bogue-gas-conversion-project/

59 http://jamaica-gleaner.com/article/business/20160506/bogue-plant-conversion-wrap-next-week

60 https://www.icis.com/resources/news/2017/02/23/10081759/corrected-centrica-wins-three-year-Ing-supply-deal-to-jamaica/

${ }^{61} \mathrm{http}: / /$ www.jamaicaobserver.com/business/LNG-ushers-in-price-stability---JPS 70851

62 http://jamaica-gleaner.com/article/commentary/20160210/lng-cheap-think-again

63 http://www.km-advisorsllc.com/news/2017/3/23/old-harbour-190-mw-lng-to-power-project-reaches-financial-close

64 NFE South Holdings, Environmental Impact Assessment, Sept 2016. http://savegoatislands.org/wpcontent/uploads/2016/09/NFE OldHarbour EIA Report Sep2016.pdf

${ }^{65} \mathrm{http}$ ://www. Ingworldshipping.com/news/view,cheers-jamaicas-red-stripe-brewery-switches-to-Ing 48044.htm
} 

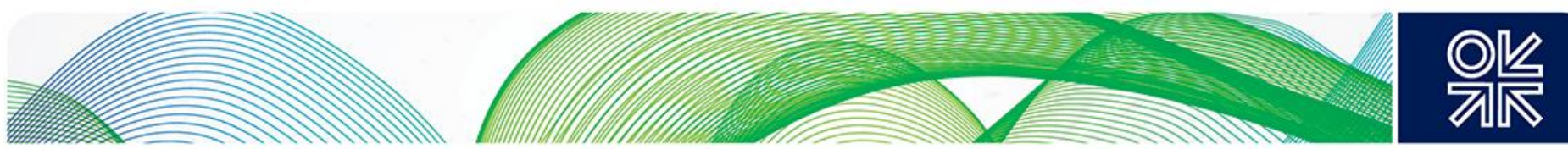

NFE and the government have suggested that the floating storage unit may also become a hub for LNG supply to other islands in the region. This appears logical, but would likely be in competition with potential supplies from the Dominican Republic and Panama.

\subsection{Panama}

\section{Economy and Energy Context}

The population of Panama reached 4.1 million in 2017, with a demographic growth of $1.6 \%$ per annum. More than $50 \%$ of the population lives in the Panama City-Colón metropolitan region. The country's GDP growth in 2015 was $6 \%$ compared to a meagre $0.2 \%$ in Latin America. The Government projects that the economy will grow 5.8\% in 2017.

Panama is a dollarised free-market economy which relies heavily on the services industry, banking, commerce and tourism. The expansion of the Panama Canal and investment in infrastructure (energy, transportation, construction) have contributed to a strong economy.

The industrial sector manufactures aircraft spare parts, cements, drinks, adhesives, and textiles. Panama's main exports are bananas, shrimps, sugar, coffee, and clothing.

Figure 10: Panama vs Latin American and the Caribbean GDP growth (\%)

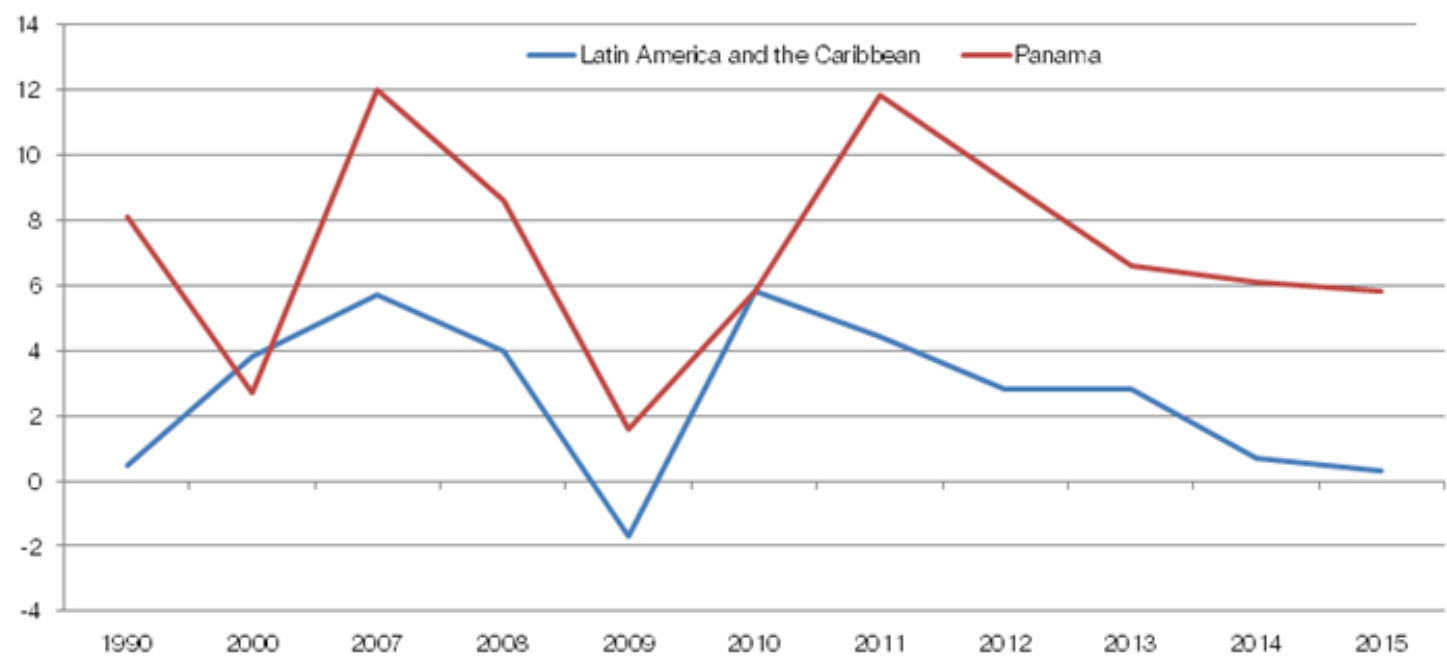

Source: https://www.weforum.org/agenda/2017/04/panama-s-secret-to-economic-growth-immigrants/

The energy sector in Panama

The energy matrix in Panama is heavily dependent on oil and oil products. In 2016 Panama imported $28 \mathrm{MM}$ bbls of oil products. 

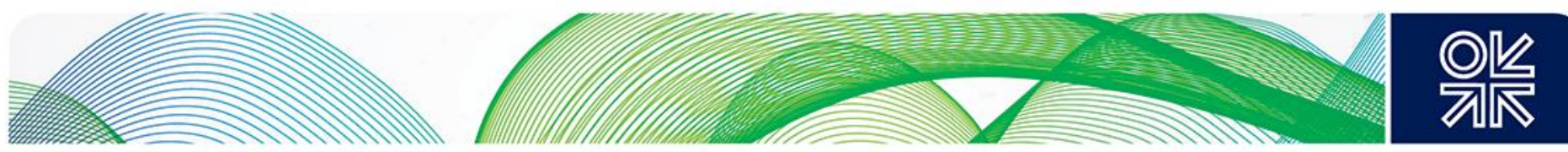

Figure 11: Panama: evolution of the supply of energy

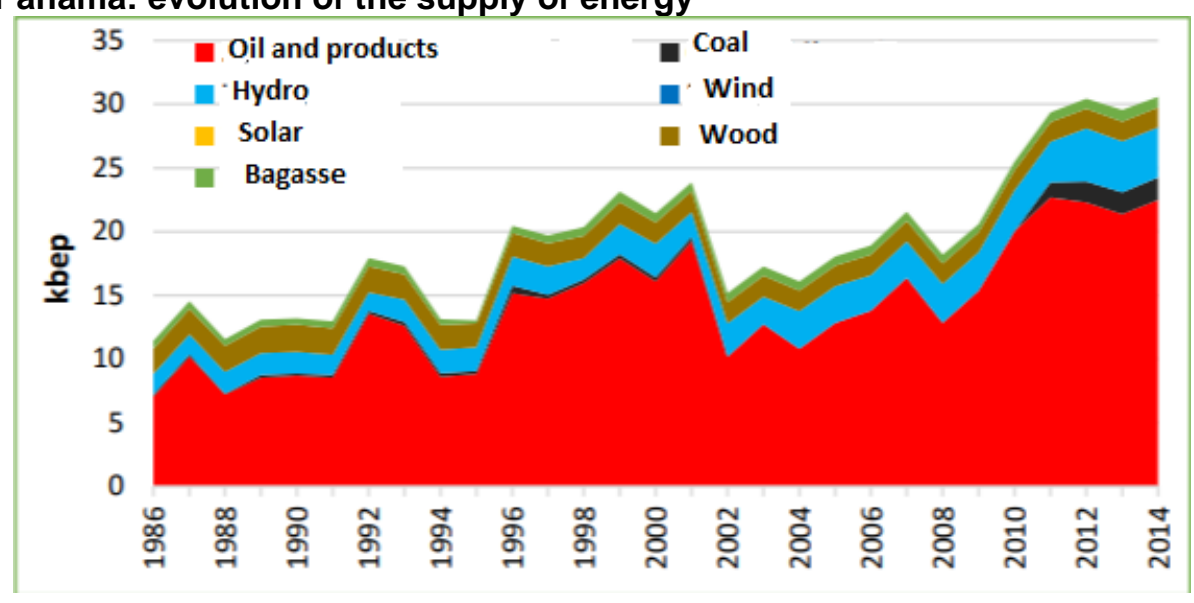

Source: Adapted from (Secretaria Nacional de Energia - Panama (b), 2015)

Panama has relied mainly on hydroelectric generation to meet its electricity needs. The government has been encouraging a change in its energy mix due to the impact of climate change and phenomena such as El Niño on the country's hydro reservoirs.

In 1998 Panama restructured its electricity sector with the subsequent privatisation of its integrated state-owned electricity company (IRHE). The government allowed private participation in generation and distribution of electricity but retained full control of the transmission system. The National Secretariat of Energy is responsible for planning and policy making whereas the regulation of the electricity sector was assigned to the National Authority of Public Services (ASEP).

The Panamanian electricity system consists of over 60 generation plants, a state-owned transmission company (ETESA) and three distribution companies (ENSA, Edemet and Edechi) in which the government has a non-controlling participation. In 2005, ASEP granted another transmission concession to Empresa Propietaria de la Red (EPR), which is in charge of interconnecting the Central American electricity market under the Central American Electrical Interconnection System (SIEPAC) treaty ${ }^{66}$.

Generators must enter the market through a concession or a licence granted by ASEP. Hydro and geothermal generators must obtain a concession. All other technologies must obtain a licence. Generators can sell their power through (a) power purchase agreements (PPAs) with distribution companies awarded through auctions; (b) PPAs freely negotiated with other generators or large unregulated consumers whose demand exceeds $100 \mathrm{~kW} /$ month (LUCs); (c) PPAs with the large consumer basket (LCB) which is a collection of all electricity requirements from LUCs managed by the state-owned transmission company (ETESA); or (d) the spot market.

Distribution companies must keep open access to their grids for all generators and LUCs, subject only to payment of tolls and connection charges.

As of December 2016, the total installed capacity was 3,369 MW, with a maximum peak demand of 1,657 MW achieved in April 201767. The system generated 10.9 GWh in 2016, with predominance of hydro and bunker oil.

In 2016 renewable energy accounted for $63 \%$ of the total installed capacity, of which hydro corresponded to $1,767 \mathrm{MW}$ and wind accounted for $270 \mathrm{MW}$. Thermal generation capacity totalled 1,235 MW, of which $296 \mathrm{MW}$ was based on fuel oil, $419 \mathrm{MW}$ on diesel and $120 \mathrm{MW}$ on coal (Figure).

\footnotetext{
${ }^{66}$ (Secretaria Nacional de Energia (a), 2017; Secretaria Nacional de Energia (a), 2017)

${ }^{67}$ http://www.energia.gob.pa/Compendio-Estadistico-Energetico
} 

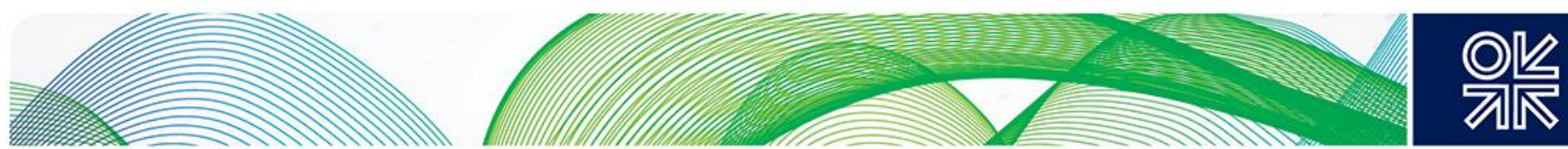

Figure 12: Panama: share of installed power capacity (2016)

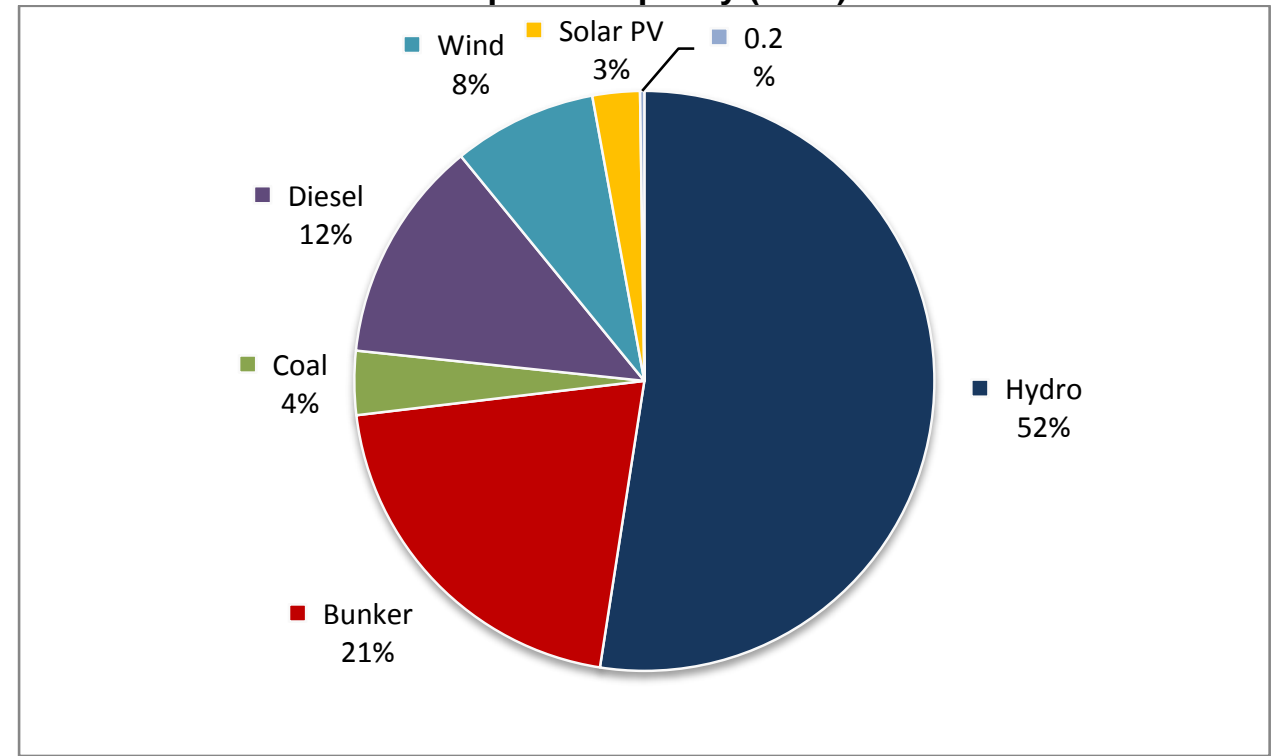

Source: http://www.energia.gob.pa/Compendio-Estadistico-Energetico

Panama expects that its energy demand will grow at an average rate of $6 \%$ until 2030 , by when it should almost double to $21,000 \mathrm{GWh}$, according to the projections included in the 2015/2050 National Energy Plan. ${ }^{68}$ The growth in demand will be spurred by expansion of the Panama Canal, new airport operations and a new potable water and sewerage system. According to the plan, total installed capacity is expected to reach 5,064 MW in 2020 and 5,862 in 2030. There is scope for importing LNG to supply approximately $900 \mathrm{MW}$ by 2030 in addition to the current AES LNG project requirements.

\section{LNG import project}

In 2015 an AES subsidiary (Gas Natural Atlántico) won a competitive tender conducted by Panama's Electric Transmission Company (ETESA), to supply $350 \mathrm{MW}$ of new generation capacity. The winning price was USD 113.48/MWh ${ }^{69}$. The USD 1.1 billion project comprises the construction of a $380 \mathrm{MW}$ combined cycle natural gas-fired plant, with a 10-year 350 MW Power Purchase Agreement (PPA), and an LNG terminal (Costa Norte LNG) comprising a 180,000 $\mathrm{m}^{3}$ storage tank and regasification facility designed to supply gas to the power plant and other regional markets. The project also comprises a $230 \mathrm{~kW}, 17 \mathrm{~km}$ power line connecting the plant to the ETESA system.

The terminal has been designed with two LNG truck-loading bays, which can supply $68 \mathrm{~m}^{3} /$ hour of LNG.

Costa Norte LNG is owned $50 \% / 50 \%$ by AES and its local partner Inversiones Bahía. The total capacity of the terminal is approximately $1.5 \mathrm{mtpa}$, of which $0.4 \mathrm{mtpa}$ will be used for the $380 \mathrm{MW}$ AES Colón CCGT power plant.

\footnotetext{
68 (Secretaria Nacional de Energia - Panama (b), 2015; Secretaria Nacional de Energia - Panama (b), 2015; Secretaria Nacional de Energia (a), 2017)

${ }^{69} \mathrm{http}: / /$ www.monografias.com/docs112/panama-innovando-planta-gas-natural/panama-innovando-planta-gas-natural.shtml
} 

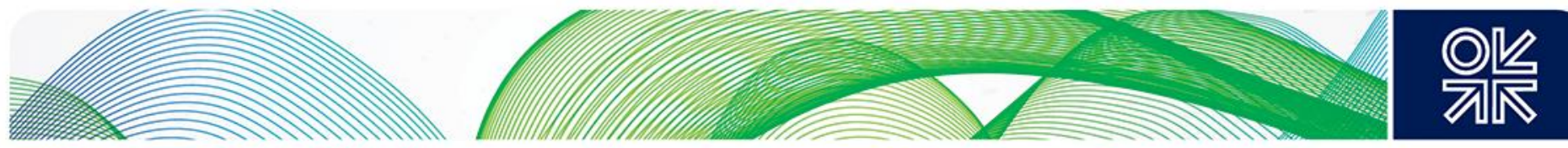

Figure 13: Panama: construction site of AES LNG terminal

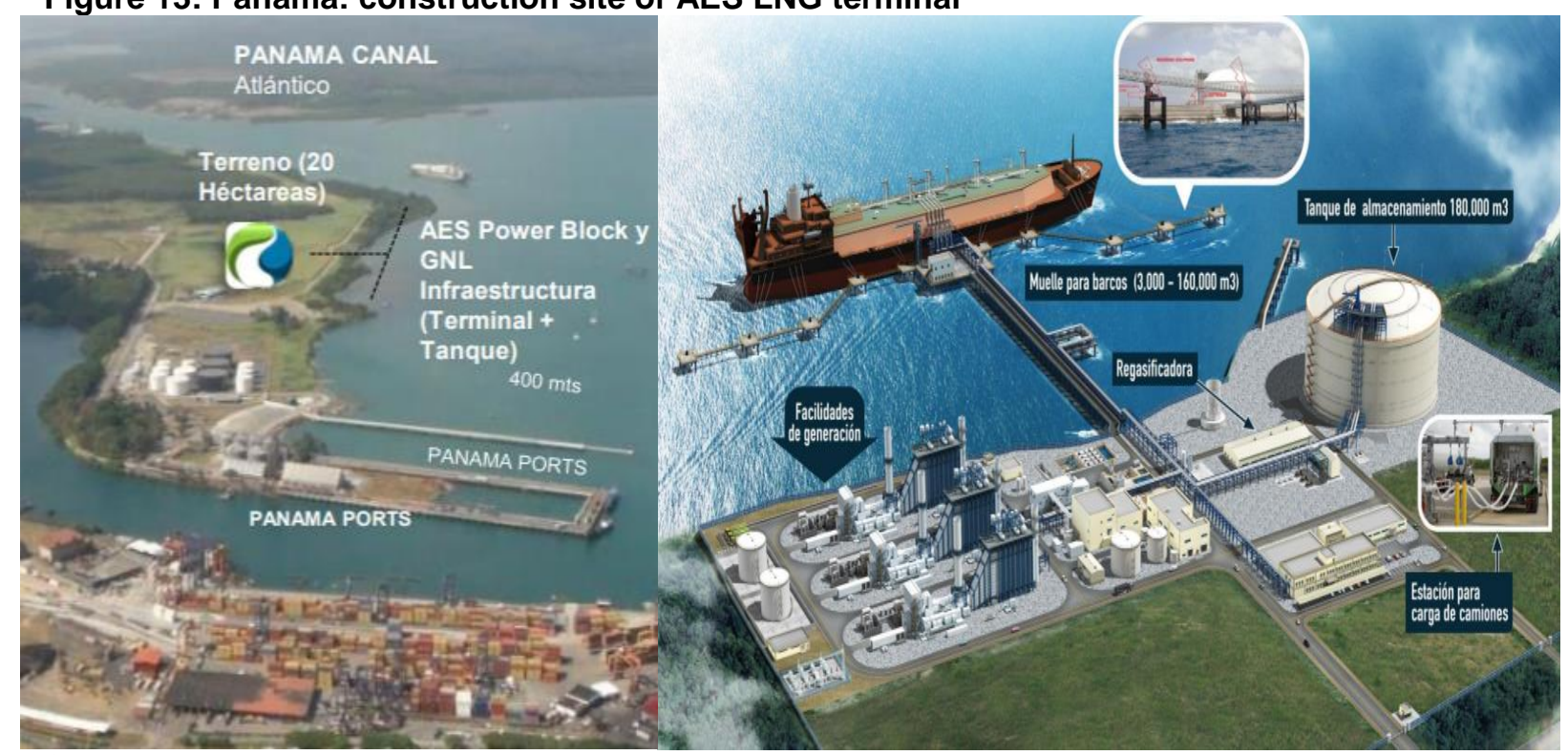

Source: (Bolinaga, 2017)

The EPC contract for the LNG terminal and power plant was awarded to South Korean Posco E\&C. In 2016 AES awarded a contract to BAM International and Iconsa to build an LNG jetty in Costa Norte, at the Caribbean entrance of the Panama Canal. Construction started in the first quarter of 2017, with expected completion in 2018-2019. The Costa Norte LNG terminal will accommodate vessels with capacity ranging between 30,000 and $180,000 \mathrm{~m}^{3}$. The French group ENGIE will provide up to 0.4 mtpa of LNG to the project.

\section{Outline Commercial Structure}

The 381 MW AES Colon power project was awarded via a power tender organised by ETESA in 2015. The project includes the power plant (AES Colon) and the LNG terminal (Costa Norte LNG). The power plant signed a 10-year, $350 \mathrm{MW}$ PPA with the Panamanian power distribution companies and will receive an annual capacity payment equivalent to USD 163 million.

In 2016 ENGIE and AES Andres DR, S.A. (AES Andres) agreed to enter into a binding joint marketing agreement for LNG for a period of up to 12 years. Under the agreement, ENGIE will deliver up to 0.7 mtpa from its LNG portfolio, primarily via its supply from the Cameron gas liquefaction project in the U.S., expected to come on line in 2018. AES Andres will provide access to its regasification assets in the Dominican Republic and Panama, which have an annual combined capacity of approximately 3 mtpa.

ENGIE will supply up to 0.4 mtpa to the Colon CCGT, beginning in 2018. The remaining Costa Norte terminal capacity will be available for the joint venture to market and sell to third parties. The JV partners will target industrial, transport and small-scale demand. They also plan to provide regional bunkering services.

\section{Other proposed LNG projects}

In parallel, another LNG-to-power project is being developed by Martano Inc., a power generation company established in 2007 in Panama which is owned by China's Shanghai Gorgeous Investment Development Co, Landbridge Group and Barbados-based Termogas Group. In 2015, ETESA awarded Martano a 15-year concession to build and operate a $400 \mathrm{MW}$ combined-cycle natural gas 

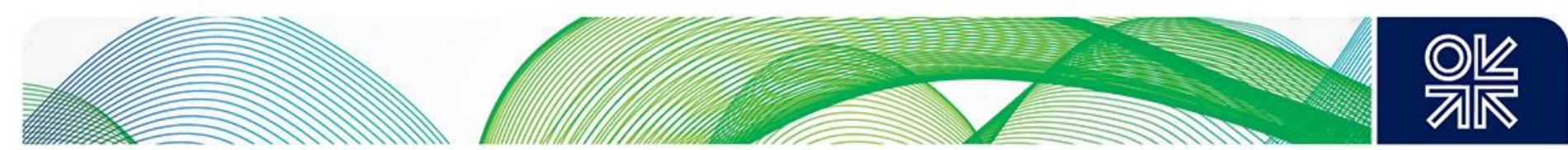

plant in Isla Margarita, in the province of Colon (Project GAS TO POWER PANAMA - GTPP)..$^{70}$ The winning price was USD 84.95/MWh. Martano is proposing to build anLNG terminal with storage capacity of $185,000 \mathrm{~m}^{3}$ to supply the power plant and industries in the area. LNG would be imported from Australia through Landbridge affiliate Westside Corp.

Electricity prices in the spot market have softened considerably in 2017 due to a combination of wet season and low oil price. The marginal cost of the system was USD 29/MWh on average in September 2017 compared to USD 78.9/MWh in September 2015 and USD 92.2/MWh in January $2015^{71}$. It is yet to be seen how the LNG-cum-power projects in Panama will be dispatched if spot prices continue to weaken and LNG prices start to ramp up after 2020.

\subsection{Other markets}

A significant number of other countries in the Caribbean region either are currently developing plans for importing LNG, or have announced the intention to do so over the last few years. This section gives a brief summary of those plans and our current understanding of their status. In general, it should be noted that several projects have been announced and, in some cases, even broken ground, but have then not progressed as expected. For smaller markets, there appear to be a growing number which are considering LNG imports by ISO-containers, which can be transported along with other cargo on a general purpose container ship.

\section{AES hub and spoke model}

AES is proposing to use its $L N G$ import assets in the Dominican Republic and Panama to develop a hub and spoke business model, comprising the re-export of LNG from DR and Panama to supply of LNG to smaller markets via small-scale LNG ships, ISO-containers, bunkering services and re-load of LNG. The Andres terminal is being reconfigured to allow reload break-bulk and bunkering services. A multiple destination LNG supply deal with ENGIE will facilitate exports to regional markets.

However, it is not clear whether the host government in the new importing countries will support investment in terminal facilities and whether AES will participate in the downstream market.

Figure 14 below illustrates how the model would take advantage of the existing importing facilities.

Figure 14: Proposed Hub and Spoke LNG distribution mode for Central America and Caribbean

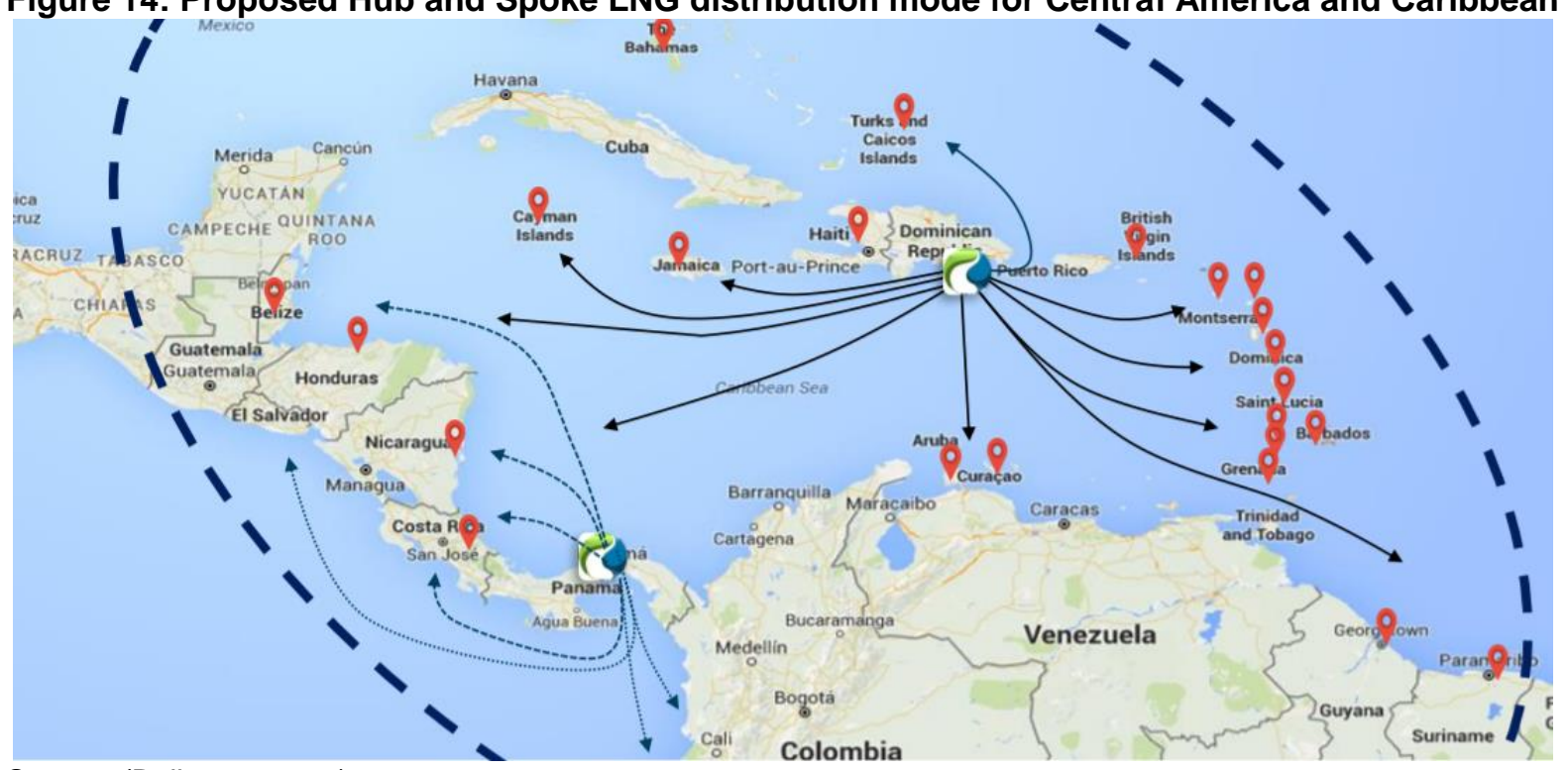

Source: (Bolinaga, 2017)

\footnotetext{
${ }^{70} \mathrm{http}: / /$ www.asep.gob.pa/www/pdf/anno_9342_elec.pdf

${ }^{71} \mathrm{http}: / /$ www.energia.gob.pa/tmp/file/303/An\%20Merc\%201501.pdf
} 

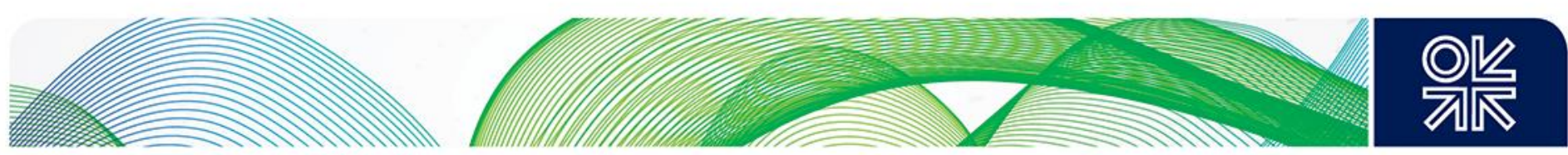

\section{Barbados}

Barbados has very small oil and associated gas production ( $<5 \mathrm{mmscf} / \mathrm{d}$ gas production) in operation since the 1970s, with a small gas distribution grid. ${ }^{72}$ In 2016, Barbados started to import US LNG in ISO-containers, paying prices between USD10 and USD15/MMBtu. ${ }^{73}$ Through 2017, such imports continued at a rate of about $15-20 \mathrm{mmscf} / \mathrm{month}$, such that between January and August 2017, $0.13 \mathrm{Bcf}$ of natural gas had been exported in this way. ${ }^{74}$ In May 2017, AES Dominicana signed an agreement to supply LNG to Barbados National Oil Company from its Andres LNG terminal in the Dominican Republic. LNG will be loaded at the truck loading facility and transported via ISOcontainers.

\section{Bermuda}

A report, "Viability of Liquefied Natural gas in Bermuda" was submitted by the consultancy company Castalia to the Government of Bermuda in Sept 2015, with a final version in March 2016. ${ }^{75}$ This report had the following key points:

- Bermuda imports oil products for nearly all energy needs (1.6 MM bbls in 2014 - 40\% HFO, 36\% diesel, $12 \%$ gasoline, $9 \%$ Jet A 1 ). Electricity generation is $54 \%$ of oil use, transport $44 \%$.

- Electricity demand is forecast to grow from $620 \mathrm{GWh}$ in 2016 to $647 \mathrm{GWh}$ in 2025. Installed capacity of $175 \mathrm{MW}$, vs. peak demand of $107 \mathrm{MW}$ (16\% down from $123 \mathrm{MW}$ in 2010).

- Bermuda Electric Light Company (BELCO) is the monopoly transmitter, distributer, retailer. Generates $99 \%$ of electricity consumed in the country at central Pembroke Power plant (82 MW): $80 \%$ heavy fuel oil $/ 20 \%$ diesel mix.

- Assumed gas for power gen $15 \mathrm{mmscf} / \mathrm{d}$ to 2025 .

- Conclusion that LNG can be delivered to power plant in Bermuda (using small $10,000 \mathrm{~m}^{3}$ vessel) at between USD11.7 and 16/MMBtu - between 15 and 40\% cheaper than final delivered cost of oil products.

Following this report, it appears from recent press reports ${ }^{76}$ that Bermuda is still considering whether and how to proceed with implementation of LNG imports.

\section{Bahamas}

In 2003, an environmental impact statement was approved by the Bahamian government for construction of an LNG import terminal at Ocean Cay by AES Ocean LNG. ${ }^{77}$ AES had been expected to start construction of the terminal in 2008, but following repeated opposition from local environmental groups, this did not proceed. As recently as May 2017, however, AES was proposing that the Bahamas could be supplied from its Dominican Republic terminal. ${ }^{78}$

\section{Haiti}

In August 2013 construction started on an LNG import terminal located $14 \mathrm{~km}$ north of the capital, Port-au-Prince and estimated to cost USD52.3m, with $15,000 \mathrm{~m}^{3}$ of storage $\left(15 \times 1000 \mathrm{~m}^{3}\right.$ bullet tanks), and including a truck loading facility. ${ }^{79}$ The current status of that terminal is unclear, but given the time which has elapsed and the absence of further information, we assume that construction has been suspended.

\footnotetext{
72 http://www.energy.gov.bb/web/history-of-hydrocarbon-production-in-barbados

https://energy.gov/sites/prod/files/2016/09/f33/LNG\%202016.pdf and http://www.cnc3.co.tt/press-release/us-Ing-breakscaricom-market-barbados-now-importing-Ing-united-states

${ }^{4}$ US DOE: LNG Monthly, August 2017 https://energy.gov/fe/downloads/lng-monthly-2017

${ }^{75}$ https://www.gov.bm/sites/default/files/Viability-of-Liquefied-Natural-Gas-in-Bermuda.pdf

76 http://www.royalgazette.com/business/article/20170721/expert-sees-value-in-Ing-option-for-bermuda/1

http://www.hydrocarbons-technology.com/projects/oceancaylngterminala/

78 http://www.tribune242.com/news/2017/may/12/multi-billion-group-very-interested-bahamas/

79 http://www.saisperspectives.com/2014issue/2014/10/12//ng-imports-a-case-study-in-developing-haitis-energy-sector-
} 

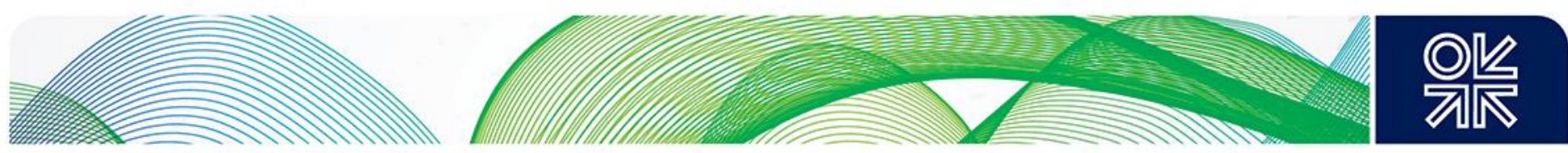

\section{Logistics, operational and commercial issues: LNG and small markets}

As noted in the introduction, the development of LNG imports in the Caribbean is of interest to the wider LNG industry, because of the fundamentally different characteristics of the region and the market when compared with traditional LNG import countries. These differences have required development of innovative approaches to logistics, operational and commercial issues, which may serve as a model to be followed by other regions.

In the first phase of the LNG industry, until the early 2000s, LNG buyers were traditionally large, highly creditworthy utilities in mature, developed economies (e.g. Tokyo Electric in Japan, Korea Gas in South Korea, and various European utility companies). At that stage any LNG supply would need a long-term, take or pay contract (typically 20 years), an onshore LNG terminal with large, expensive storage, and a secure offtake either into an established utility gas company or into a large integrated power utility. In such a model, it was relatively straightforward to secure a creditworthy revenue stream to underpin the required infrastructure investments.

In the next phase of development of the industry in the early 2000s, starting with Excelerate's development of the Gulf Gateway in the US, the advent of Floating Storage and Regasification Units (FSRUs) opened a more flexible route to LNG imports without the need for an onshore regasification terminal. The recent OIES paper by Brian Songhurst, considers the topic of FSRUs in detail. ${ }^{80}$ Such FSRUs, however, still required a reasonably large (around $1 \mathrm{mtpa}$ LNG or 1,000 MW power generation equivalent) and predictable throughput in order to be able to justify the investment and finance the project. One key benefit of FSRUs over land-based terminals, however, was to protect at least part of the investment against changing market conditions. This has been clearly demonstrated in the US, including the original Gulf Gateway project, where, as the envisaged requirement to import LNG was changed by the development of large quantities of shale gas, the FSRUs assigned to US import terminals have been redeployed elsewhere in the world.

In this latest phase of LNG market developments, exemplified by the Caribbean, some key challenges come from:

- Significantly smaller demand, typically with individual power stations of 100-200 MW or less;

- Lack of existing gas infrastructure, making it necessary to develop the entire value chain, typically through development of a gas-to-power project, rather than merely constructing an LNG import terminal to supplement existing gas supply;

- Lower creditworthiness of most countries and counterparties in the region, increasing the challenge of securing a bankable revenue stream. Most countries in the Caribbean are below investment grade or highly speculative and may require multilateral support to implement LNG projects (Appendix, Table 6). In addition, the devastation caused by hurricanes Irma, Jose and Maria in 2017, will certainly impact the ability of many Caribbean countries to host LNG projects. The high risk of future hurricanes will also impact the availability of safe harbours to shelter LNG ships and tanks.

- Electricity distribution companies are often state controlled, with a consistent track record in not staying up-to-date with payments to power generators. For example, in the Dominican Republic the government usually enters into factoring transactions, selling the distribution companies receivables to banks. In 2015, despite lower energy prices, the outstanding receivables for the AES plants were at 5.2 months of sales. ${ }^{81}$

On the positive side, project viability has been helped by the fact that most Caribbean markets have been almost completely dependent on oil products to meet their power generation and other energy

\footnotetext{
80 The Outlook for FSRUs, OIES, July 2017

${ }^{81}$ (AES Dominicana, 2016)
} 

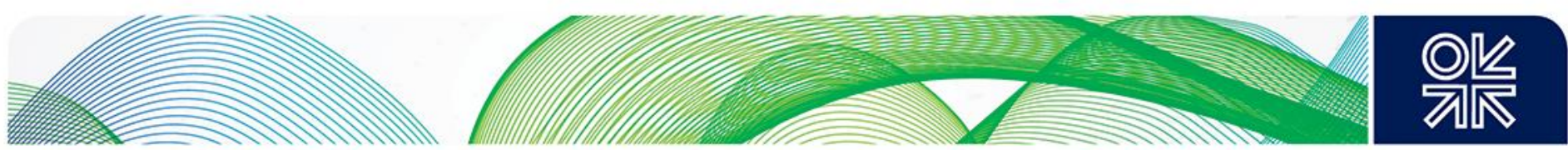

needs. This has meant (a) that regasified LNG is competing with an expensive alternative fuel, and (b) that it has been relatively easy for gas to achieve a reasonably high and predictable load factor, and (c) that gas will have a lower marginal cost of generation than the liquid fuel alternatives. To some extent, however, the promotion of intermittent renewable power generation (solar and wind) may run counter to point (b) above, thereby reducing the gas-fired load factor and making it more difficult to justify the required infrastructure investments.

\section{Electricity pricing policies and regulation of the gas and electricity markets}

\subsection{Tariffs}

The Caribbean average electricity price is very high, around USD 300/MWh and, in theory, it is attractive to enable the conversion of diesel and HFO plants to LNG.

In line with oil prices, power tariffs have gone down considerably in the region. In 2013 a study published by the International Development Bank (IDB) summarised the average electricity tariff in seven Caribbean Islands. ${ }^{82}$ Except for the Dominican Republic the average tariff was above USD $0.30 / \mathrm{kWh}$. Fuel costs accounted for $50-70 \%$ of the electricity generation costs.

In 2016 the US Department of Energy National Renewable Energy Laboratory (NREL) produced an overview of the power sector in the Caribbean Islands and calculated an average tariff of USS $0.33 / \mathrm{kWh}$ for the region, with a downwards trend in most countries due to lower oil prices.

In 2014/2015, because of lower oil prices, the tariffs were 15-28\% lower than in 2012. In 2016 there were further reductions. For example, in the case of Grenada, the average tariff in 2013 was equivalent to USD $0.38 / \mathrm{kWh}$, of which USD $0.23 / \mathrm{kWh}$ was fuel costs and USD $0.15 / \mathrm{kWh}$ non-fuel charges. In 2016 the average tariff went down to USD 0.24/kWh, of which USD 0.09/kWh was fuel costs and USD 0.15/kWh non-fuel charges.

Figure 15: Electricity tariffs in eight Caribbean Islands (USD/kWh)

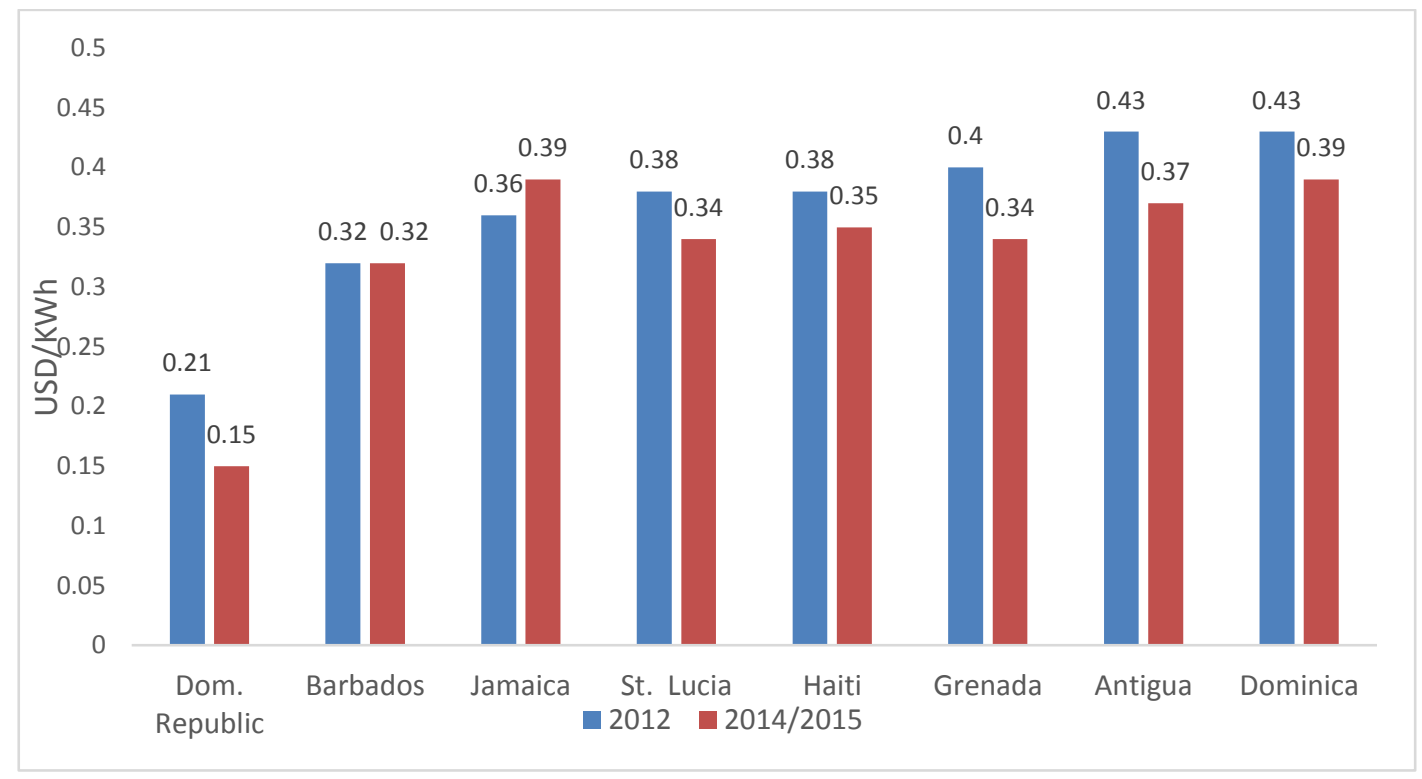

Source: (Bailey, 2013), (NREL - Department of Energy, 2016)

82 (Bailey, 2013; Di Bella, 2015) 

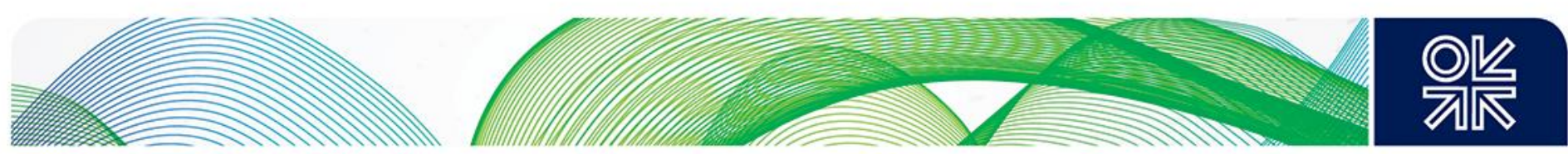

The tariffs in Central America range from USD 0.14 (Honduras) to $0.32 / \mathrm{kWh}$ (El Salvador) ${ }^{83}$. Although electricity tariffs in 2016 are still quite high when compared to other regions in the world, the drop of oil prices is not incentivising fuel switching to natural gas if this requires additional investment in infrastructure.

Fuel oil costs account for half of the cost of the service for a power plant running on HFO. For oil prices at USD $80 / \mathrm{bbl}$ the fuel element of generation cost would be around USD 157/MWh, whereas at USD 50/bbles, the fuel element would equate roughly to USD 115/MWh.

Despite the high official tariff level, most countries in the Caribbean and Central America subsidise electricity prices to a broad range of consumers. A study prepared by the IMF shows that energy subsidies in Latin America and the Caribbean (LAC) amounted to about 1.8\% of GDP, on average, in 2011-13, with fuel subsidies representing about $1 \%$ of GDP, and electricity subsidies accounted for circa $0.8 \%$ of GDP 85 . Subsidies started to ramp up when oil prices increased in the mid-2000s. The drop in oil prices provided the opportunity for governments to remove or gradually rationalise subsidies.

For example, Panama and Honduras provide subsidies for consumers of below $300 \mathrm{kWh} / \mathrm{month}$. In Nicaragua low-income consumers, below $150 \mathrm{kWh} / \mathrm{month}$, and pensioners pay subsidised tariffs through a direct budgetary transfer. As of January 2017 the fund created in El Salvador to administer subsidies ${ }^{86}$ to households has been unable to reimburse debt of USD 53 million to the power distribution companies. This has had a deleterious impact in the Electricity Wholesale Market.

In addition to introducing market distortions and diverting resources which could otherwise be invested in other public services, subsidies also reduce the payment capacity of the power distribution companies, which ultimately provide the PPAs underpinning LNG importation projects.

\subsection{Regulation}

There are three prevailing institutional models for the power market in the region. The first model consists of vertically integrated and privately owned utilities, such as in Jamaica, the Bahamas and Barbados (where the government has a small shareholding). The second model, consists of a vertically unbundled electricity market with a mix of private/government ownership in generation, government owned transmission and government-owned distribution companies that buy power from IPPs and state-owned producers. This is the case of Panama and the Dominican Republic. The third model consists of vertically integrated state-owned utilities, for example in the case of Belize, Haiti, and Trinidad and Tobago. In a few countries the government-owned companies purchase some of their electricity from independent producers.

In most countries there is a regulatory authority for the electricity services, which would possibly regulate the gas industry, should the latter develop further. Until the rise in oil prices, the usual approach of government and regulators was to maintain the existing power generation system and add fuel oil-based capacity when required. Fuel prices were passed through the tariffs to the end consumers and there was little incentive for efficiency. The rise in oil prices after 2010 resulted in increased tariffs and raised public concern.

Gas importing countries such as the Dominican Republic and Panama have established, or are proposing, a regulatory framework for the importation of LNG and the transportation, commercialisation and distribution of natural gas. On the other hand, in Jamaica, the construction of the LNG/power project preceded the implementation of a regulatory framework for natural gas, despite a comprehensive study conducted by private consultants in 2013 at the behest of the Ministry

\footnotetext{
33 (Navarrete, 2017)

${ }^{84}$ (Bailey, 2013)

85 (Di Bella, 2015)

${ }^{86}$ Fondo de Inversión Nacional en Electricidad y Telefonía (FINET)
} 

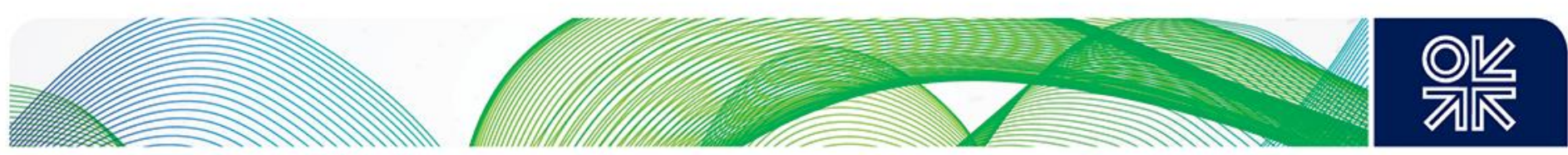

of Sciences, Technology, Energy and Mining (MSTEM). 87 The study recommended that any stakeholder proposing to operate natural gas facilities or provide natural gas services must apply for a License, whether the tariffs/rates are regulated (as between Distributors and small consumers) or freely negotiated (as among natural gas suppliers, providers of natural gas services and large consumers). Licenses should be required for the construction and operation of natural gas facilities, natural gas suppliers; and natural gas service providers. No restrictions were proposed on vertical or horizontal integration, but integrated firms were required to maintain separate accounts for each activity. The Office of Utilities Regulation (OUR) should be responsible for monitoring compliance with the Licenses and for regulating tariffs to the end users.

The Dominican Republic regulatory framework consists of Decrees and Resolutions allowing for private investment in all elements of the gas/LNG value chain. It is possible either for the government to call for tenders or for investors to propose projects directly.

- Decree 264-06 - establishes that the utilisation of natural gas is a matter of national interest.

- Resolution 121-07 regulates the use of natural gas for vehicles (NGV).

- Resolution 01-08 establishes the framework for the licensing of gas distribution and commercialisation activities.

- Resolution 25-09 establishes the requirements for the design, construction and safety of NGV conversion workshops.

- Resolution 26-09 establishes the requirements for the design, construction and safety of NGV dispensing stations.

- Resolution 27-09 establishes the procedures to license NGV related activities.

- Resolution 152-09 establishes the methodology to calculate the price of natural gas.

In Panama the government is discussing a Natural Gas Bill88, to address the deficiencies of the 1987 Hydrocarbon Law and the 1996 Law which granted to ASEP the authority to regulate the transmission and distribution services. The Bill states that the activities related to natural gas are of national interest and establishes the unbundling of the activities of transportation and distribution, negotiated prices for imported gas and projects initiated by private investors, and open access to uncontracted capacity in transportation pipelines and regas facilities subject to certain utilisation conditions. The bill has not yet been voted, therefore the construction of the AES LNG terminal and sales to the domestic market are moving forward without an encompassing regulatory framework.

The proposed regulation is in line with establishing a more transparent and unbundled regime downstream of the importation terminal and will also allow for open access to uncontracted terminal facilities. However it is not clear whether the legislation will exempt the Costa Norte LNG terminal from third party access. If the terminal is exempted then it will create a supply monopoly for AES, which will be potentially extended to the markets which would be supplied by the hub and spoke model. However due to the smaller size of the downstream market in Panama, LNG suppliers would be more comfortable if a credit-worthy buyer takes the role of aggregating demand.

\section{Analysis of the commercial model and economics of selected projects}

For this section, we analyse two recent, but contrasting, examples where LNG has been imported, Jamaica (as an example of small-scale bulk LNG imports) and Barbados (as an example of import of LNG in ISO-containers). We also provide an overview of the enabling electricity capacity mechanism and a comparative analysis of the competitiveness of LNG in Panama versus fuel oil and diesel. Information on costs and economics is typically kept confidential by the project participants, so the

\footnotetext{
${ }^{87}$ (Attwood \& Mercados, 2013)

88 (Moreno, 2017)
} 

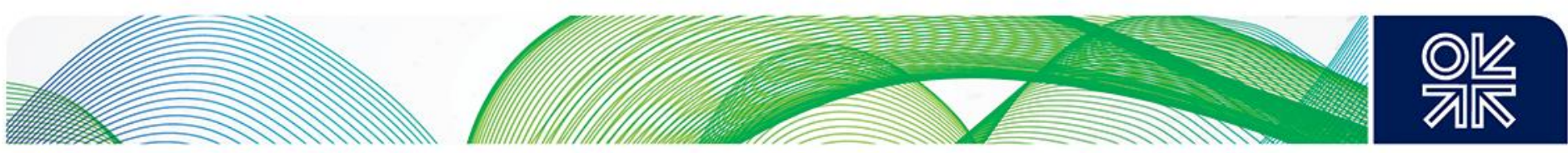

authors have made their own calculations drawing on publicly available information and their own estimates.

\subsection{Jamaica}

\section{Figure 16: Jamaica LNG Commercial Structure}

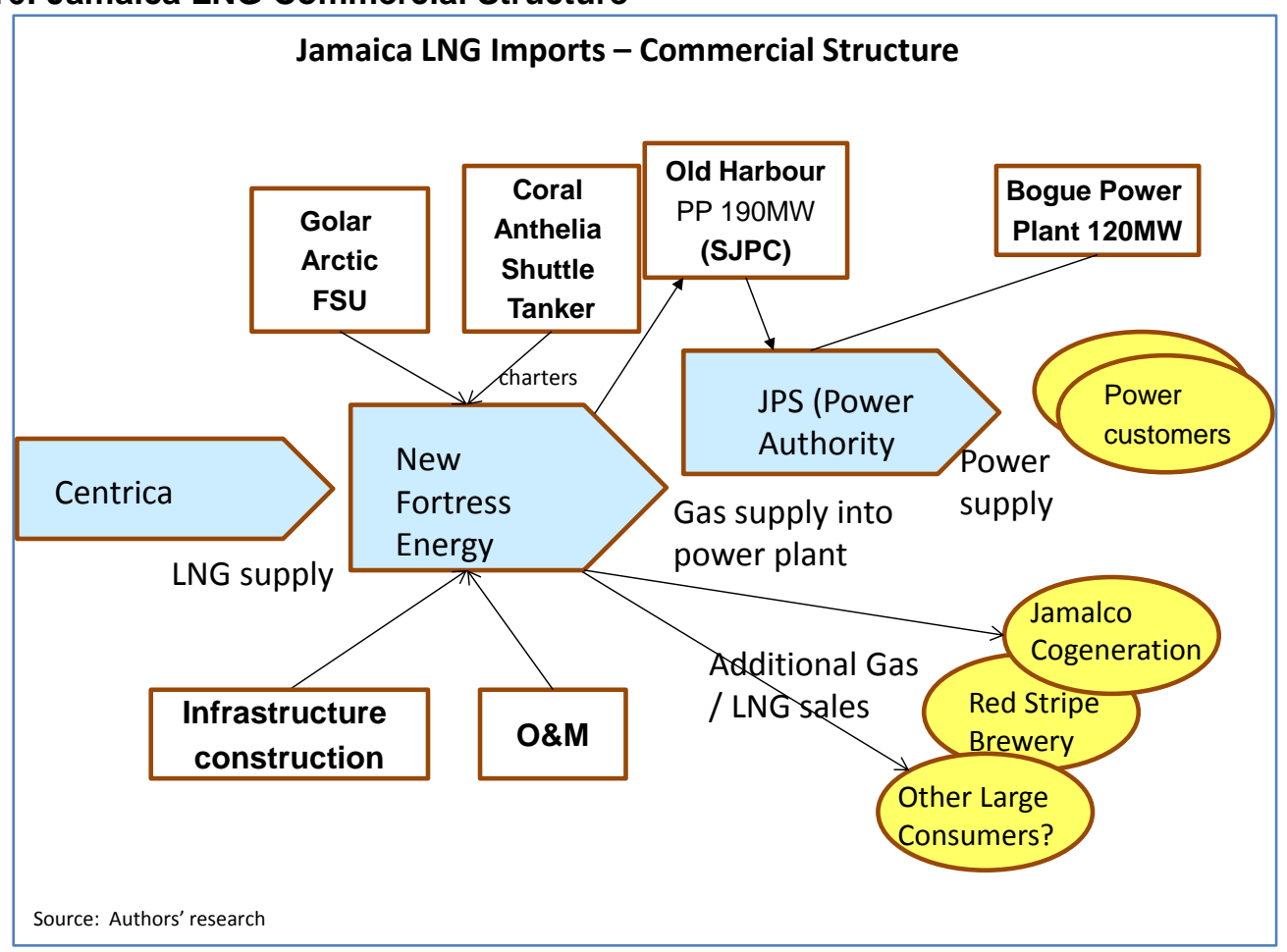

Source: Authors' research

Figure 16 illustrates the commercial structure currently used for LNG imports in Jamaica. The key players in establishing the initial LNG imports, were;

(a) the utility company Jamaica Public Service Co Ltd (JPS), now $80 \%$ privately owned by Marubeni $(40 \%)$ and Korea East-West Power $(40 \%)^{89}$ and

(b) New Fortress Energy (NFE), a division of Fortress Investment Group LLC of New York.

JPS and NFE entered a gas sales agreement, whereby JPS was responsible for conversion of the 120 MW Bogue combined cycle power plant from diesel to natural gas, and NFE was responsible for procurement of LNG and for putting in place all of the required infrastructure to supply gas to the Bogue power plant.

In March 2016, shortly after signing the initial Bogue deal in late 2015, NFE signed a second gas supply agreement with South Jamaica Power Company (SJPC), an independent power plant developer and subsidiary of JPS. Under this structure, SJPC has committed to construct and operate a new 190MW gas fired power plant, with the power to be sold to JPS under a Power Purchase Agreement.

In a third deal, in mid-2017, between NFE and Jamalco (a bauxite / alumina producer), NFE agreed to construct a 200MW combined heat and power plant, where the steam and around half the power output would be sold to Jamalco and the balance of the power output would be sold to JPS.

${ }^{89}$ JPS website: https://www.jpsco.com/about-jps/our-history/ 

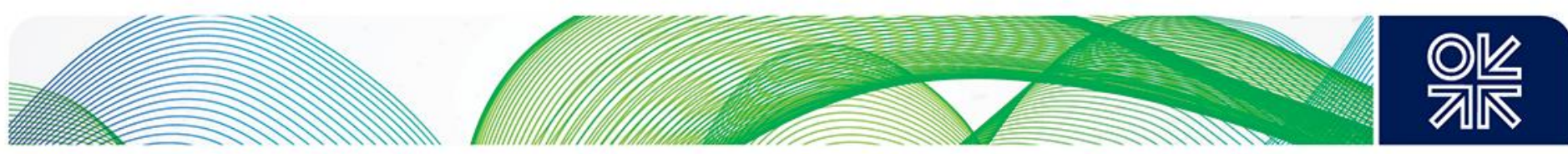

In the latest development, in June 2017, NFE has signed a deal with the local brewery, Red Stripe, to sell LNG in ISO-containers, to power the combined heat and power plant, which had previously been operating on LPG. We assume that, with the infrastructure now in place, NFE will be seeking to secure more customers in Jamaica and possibly on other nearby islands.

As described in section 3.3 above, the logistics of supplying LNG to Jamaica are relatively complex. The costs and terms of the commercial contracts have not been disclosed, but according to press reports, the landed cost of LNG is in the range USD12-15/MMBtu, more expensive than the diesel fuel it replaces..$^{90}$

We have made our own calculations to estimate the cost, which appear to confirm this level, certainly when only the initial Bogue power plant is being supplied, although costs will drop substantially once additional customers are added, thereby increasing utilisation of the (largely fixed-price) infrastructure.

As can be seen from Table 3, the cost of initial supply to the Bogue power plant only is estimated at USD13.50/MMBtu, of which nearly USD3.00/MMBtu91 is estimated to come from the high cost of burning boil off gas on the floating storage unit. This cost drops dramatically once the FSU is connected to shore and the boil-off can be piped to customers and sold.

Table 3: Cost build-up Jamaica LNG

\begin{tabular}{|c|c|c|c|}
\hline $\begin{array}{l}\text { Cost elements (in } \\
\text { USD/MMBtu) }\end{array}$ & $\begin{array}{l}\text { 120MW Bogue only } \\
\text { (via FSU, shuttle } \\
\text { tanker, Montego Bay } \\
\text { terminal) }\end{array}$ & $\begin{array}{l}\text { Plus 190MW Old } \\
\text { Harbour (terminal and } \\
\text { power plant) }\end{array}$ & $\begin{array}{l}\text { Plus Jamalco } \\
\text { (including } \\
\text { additional pipeline) }\end{array}$ \\
\hline $\begin{array}{l}\text { US pipeline gas (Henry } \\
\text { Hub) }\end{array}$ & 3.00 & 3.00 & 3.00 \\
\hline US Liquefaction & 3.00 & 3.00 & 3.00 \\
\hline $\begin{array}{l}\text { Shipping / Floating } \\
\text { Storage / Boil Off }\end{array}$ & 5.00 & 1.50 & 1.20 \\
\hline Terminal / pipeline & 2.50 & 2.60 & 1.90 \\
\hline TOTAL & 13.50 & 10.10 & 9.10 \\
\hline
\end{tabular}

Source: Authors' estimates

Given these cost calculations, it is little surprise that NFE entered additional sales contracts so soon after the initial commitment to supply the Bogue power plant. It also illustrates clearly the commercial benefit of an incumbent player owning existing infrastructure, which leads to a "natural monopoly": any new potential competitor would struggle to compete with the supply chain costs of an established player. From a national perspective, it raises the question of how such a natural monopoly should be regulated to ensure an appropriate distribution of risk and reward between the infrastructure owner and other stakeholders, notably the individual power consumers.

\footnotetext{
${ }^{90} J a m a i c a ~ G l e a n e r, 10^{\text {th }}$ Feb 2016 "LNG Cheap? Think again" http://jamaica-gleaner.com/article/commentary/20160210/lngcheap-think-again

${ }_{91}$ Out of USD 5.00/MMBtu for shipping/floating storage/boil off. Liquefaction costs at USD 3.00/MMBtu is an assessment based on the range of old and new contracts, and is deemed to include plant fuel costs.
} 

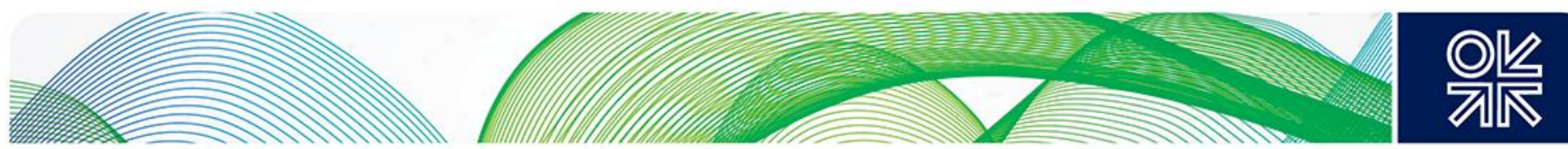

\subsection{LNG by ISO-Container (Barbados as example)}

\section{Figure 17: Barbados LNG by ISO-container commercial structure}

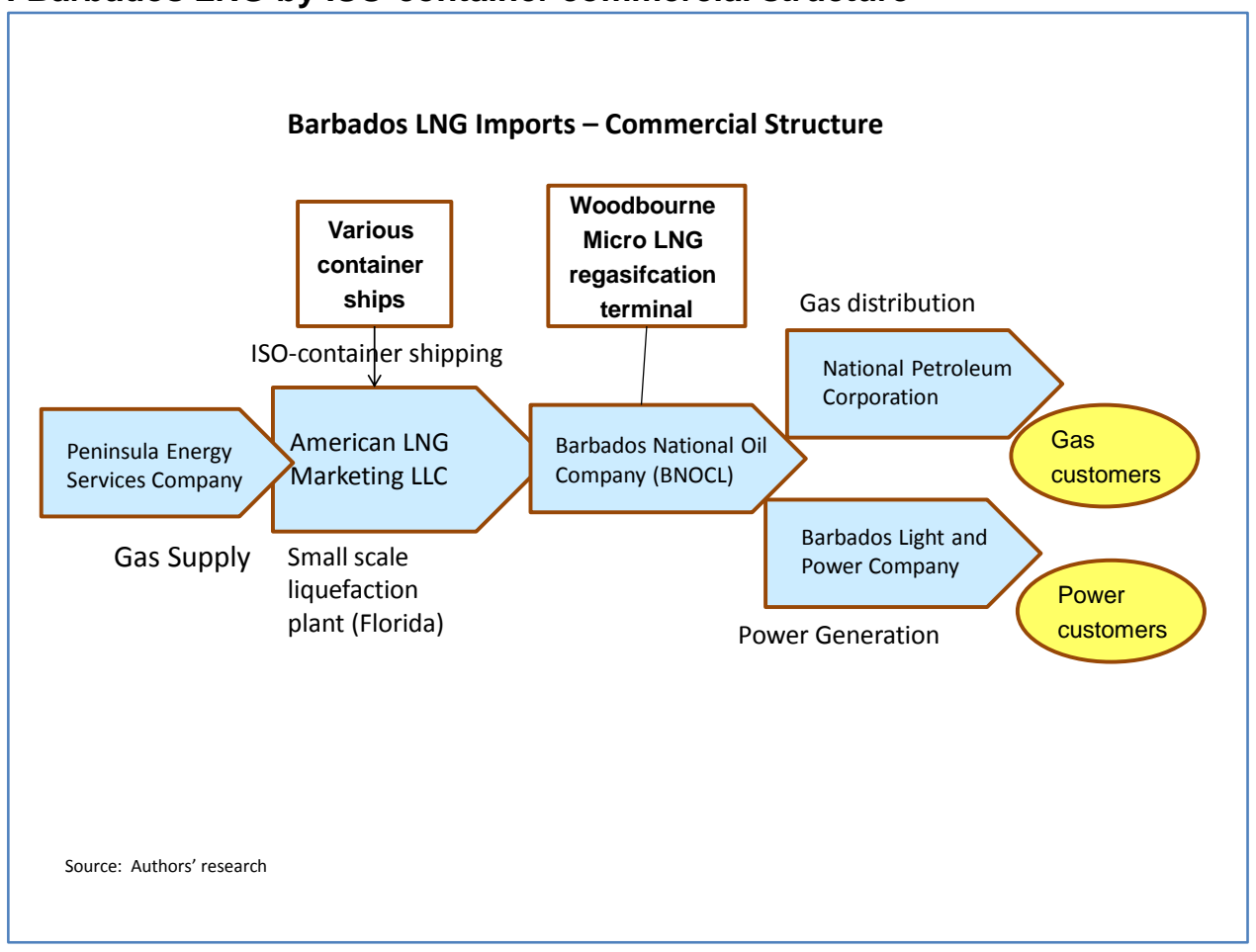

Source|: Authors' research

As noted in Section 3 above, Barbados and Puerto Rico are the first two Caribbean islands to import LNG in ISO containers. The rest of this section uses Barbados as an example. The logistics, and hence commercial structure, of the ISO-container supply chain are relatively simple, as illustrated in Figure 17 above. The LNG is manufactured in a small-scale LNG plant in Florida, by American LNG Marketing LLC, using gas purchased from Peninsula Energy Services Company (American LNG Marketing is controlled by Fortress Investment Group ${ }^{92}$, the same parent company as the infrastructure developer in Jamaica.) After loading into ISO-containers, the LNG is shipped by road and by mixed-cargo container ship to the Woodbourne regasification plant owned by the Barbados National Oil Company. From there it is sold to customers via the existing natural gas distribution system operated by the National Petroleum Corporation. Upgrades to the natural gas infrastructure in Barbados, including the Woodbourne regasification plant were financed by a USD24m loan from the Inter-American Development Bank. There are also future plans to build a new, slightly larger-scale regasification facility to supply regasified LNG to power stations operated by the Barbados Light and Power Company. ${ }^{93}$

According to data from the US Department of Energy, the price of LNG in ISO-containers at the point of export in 2017 has been USD10/MMBtu. ${ }^{94}$ We estimate that the cost of shipping an ISO container to Barbados adds a further USD1 to USD1.50/MMBtu to that cost. The unit cost of regasification depends on the level of throughput. We estimate that at current low levels of utilisation (0.2 Bcf per year) this cost could be up to USD10/MMBtu, but with plans to increase throughput to more than 1Bcf

\footnotetext{
92 Application to US DoE for Export of Natural Gas, Feb 2015:

https://www.energy.gov/sites/prod/files/2015/02/f19/15 19 Ing nussdorf 0.pdf

${ }_{93}$ IADB: Deployment of Cleaner Fuels and Renewable Energies in Barbados (BA-L1012)

https://ews.rightsindevelopment.org/files/documents/12/IADB-BA-L1012 74OHYtN.pdf

${ }^{94}$ US DOE, LNG Monthly, August 2017: https://energy.gov/sites/prod/files/2017/10/f37/LNG\%20Monthly\%202017.pdf
} 

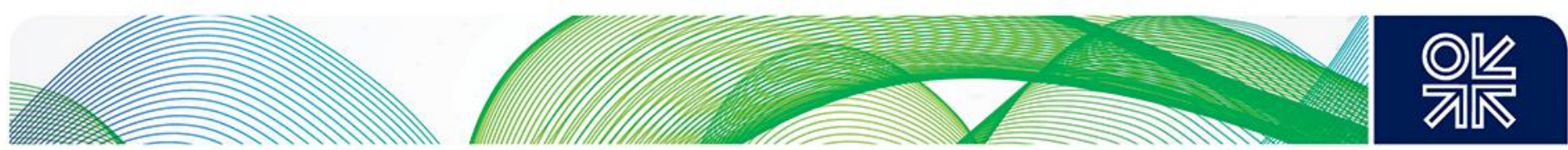

per year 95 this could be substantially reduced to around USD2/MMBtu. This would put the total cost of gas delivered via the ISO-container route at around USD13.50/MMBtu. Depending on the world oil price and tax treatment, this is likely to roughly comparable with diesel fuel, but more expensive than fuel oil.

\subsection{Panama}

As of September 2017, the prices of HFO and diesel in Panama are respectively USD 48.3/bbl and USD 79/bbl. Liquid fuel prices have come down considerably since 2013 and have recovered substantially from the lows of early 2016.

The authors assumed two price scenarios for LNG delivered in Panama, either $12 \%$ Brent DES ${ }^{96}$ or a $\mathrm{HH}$ based formula - with liquefaction costs of USD 3/MMBtu, fuel costs of $15 \% \mathrm{HH}$. In both cases an all-in cost of USD 1/MMBtu for regasification and domestic gas transportation was assumed. In both cases regasified LNG is competitive with diesel, but on a par with fuel oil. The ultimate decision making criterion for HFO users is the cost of upgrading or revamping old liquid fuel-based power plant, in the range of USD 30-50 million for 150-300 MW.

It is worth noting that despite the current scenario of abundant supply and relatively low prices, LNG is competitive in replacing diesel, but not necessarily fuel oil, in power generation. Therefore the decision to convert a power plant from fuel oil to regasified LNG will depend on the payback if the additional investment required in the conversion to natural gas.

Figure 18: Panama: Regasified LNG competitiveness vs HFO and diesel

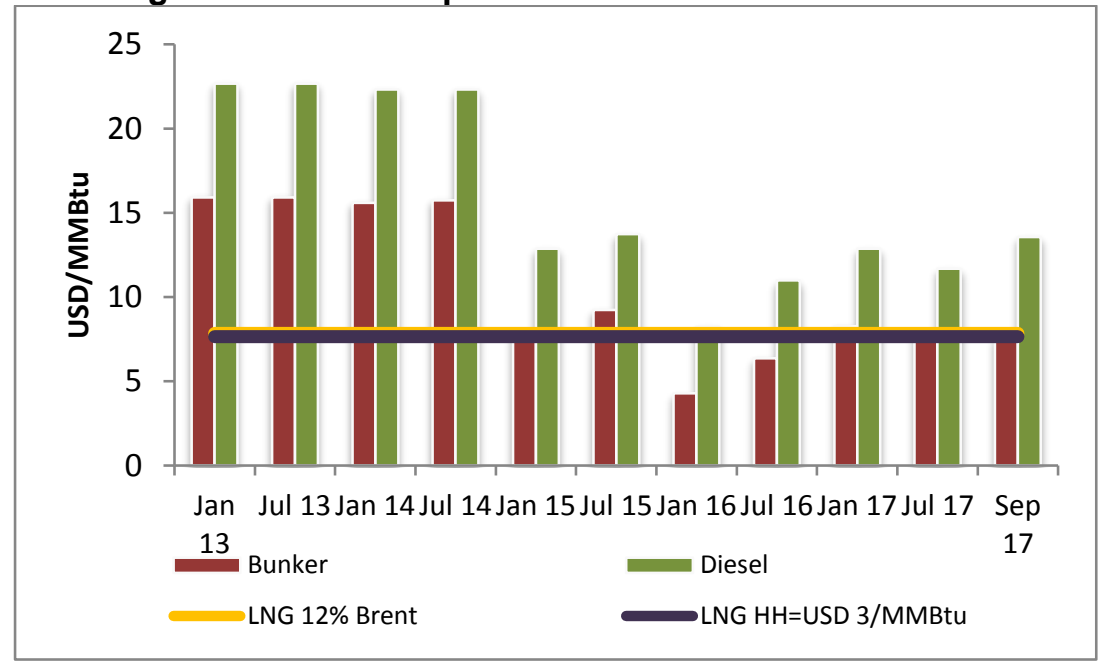

Source: Author estimate and http://www.energia.gob.pa/tmp/file/303/An\%20Merc\%201709.pdf;

The Costa Norte LNG project is underpinned by a relatively small new power plant (381 MW) and a 10-year PPA for $350 \mathrm{MW}$. Similarly to other hydro preponderant markets which are dispatched on merit and where the variable cost of water is zero, there is a risk that the LNG power plant will not be dispatched in the wet season. In the tender process, ETESA assessed bids on the basis of the lowest levelised electricity price. AES offered a high fixed price/kW (USD 38.83/kW.month), a low variable cost (USD 0.0268/kWh), giving a levelised price of USD $113.48 / \mathrm{MWh}^{97}$. The capacity payment will allow fixed revenue of USD 163 million/year. Therefore if the power plant is not dispatched AES will recover capital and fixed costs in the power plant and LNG terminal.

\footnotetext{
95 IADB: Deployment of Cleaner Fuels and Renewable Energies in Barbados (BA-L1012)

http://www.iadb.org/en/projects/project-description-title,1303.html?id=BA-L1012

${ }^{96}$ Brent = USD 57.02/bbl as of 29/09/2017

${ }^{97}$ https://www.etesa.com.pa/compras_documentos_ver.php?id=432
} 

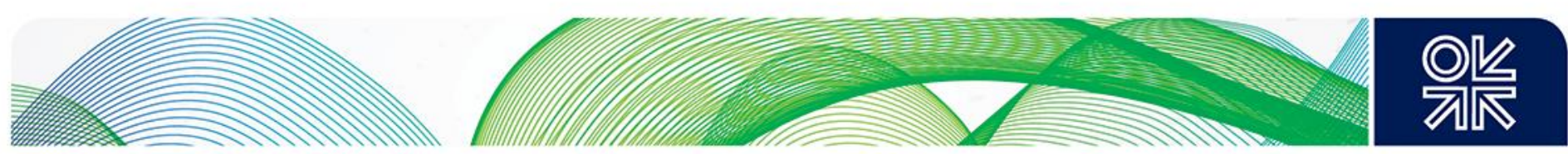

Capacity mechanisms are also being implemented in other countries with a large share of hydro power plants in the electricity mix, where the government wants to secure investment in thermal power plants to back up hydro-generation, for example in Brazil.

\section{Supportive government policies}

Besides Trinidad and Tobago, where domestic natural gas plays a key role in the power and industrial sectors, Panama is currently the only country in the region which is developing tax and regulatory measures to facilitate investment in natural gas projects, such as:

- LNG projects and gas-fired power plants benefit from tax exemption in the importation of equipment

- There is a tax credit applicable to the income tax of a maximum of $5 \%$ of the total direct investment value for civil works that become infrastructure for public domain.

- Exoneration of customs duties that could be caused due to the importation of equipment, machinery, materials, spare parts and other materials necessary for the construction, operation and maintenance of the plants.

- Right to use an accelerated amortization method to depreciate fixed assets.

- The exemption of all national taxes, for a period of 20 years, for companies dedicated to the manufacturing of natural gas generation equipment within Panama. Equipment includes mechanical, electronic, electromechanical, metallurgical and electrical types of equipment.

- Thermal power tenders allowing for capacity payment mechanism covering fixed costs for LNG and power plant.

- Pass-through of fuel costs in USD to generation prices (also applicable in DR).

Another important requirement is for governments to actively engage with multilateral agencies (IDB, World Bank) to provide payment guaranties, similar to what is happening currently in Argentina, where the World Bank is providing payment guarantees for up to 1,000 MW of renewable energy being auctioned by the government.

At the current moment, it seems unlikely that other countries will adopt natural gas/LNG supporting policies unless there is a concrete project being developed locally. They would benefit from analysing the policies being implemented in Panama to encourage investment in terminal facilities.

\section{Insights and Conclusions}

The Caribbean and Central American region provides evidence of alternative logistic and commercial models which have been used to established small scale LNG supply chains. This challenges earlier assumptions that LNG was only a suitable fuel to be sold in large quantities, typically to power plants of around $1,000 \mathrm{MW}$ or greater, to large creditworthy buyers.

While each individual market is small, with few countries with potential gas-fired power generation capacity larger than $1,000 \mathrm{MW}$, the total potential gas-fired capacity in the region could total around $20 \mathrm{GW}$, equivalent to over $20 \mathrm{Bcma}$ of gas demand.

The Caribbean region benefits from the current low price of gas in the US and the short shipping distance from established liquefaction facilities on the US south coast. However LNG will also need to compete with renewable energy, which is being largely deployed in a few larger markets, such as Panama and the island nations as well as coal-fired generation in countries such as the Dominican Republic and Panama.

The economics of the supply chain, either in ISO-containers or with small scale LNG carriers, for demand of less than $100 \mathrm{MW}$ is challenging and it is difficult for the delivered price to be competitive 

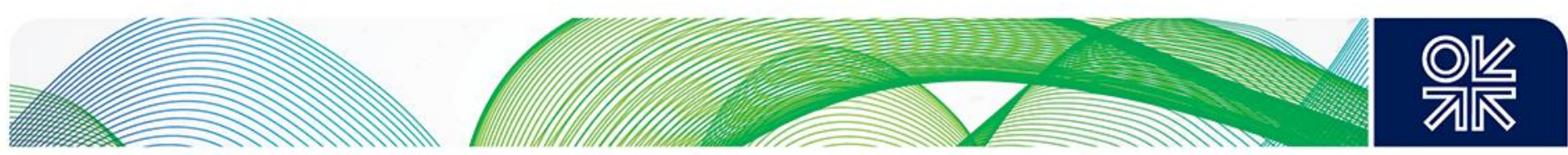

with current prices of fuel oil and diesel. Therefore different kinds of businesses have been tried in countries which are currently importing or planning to import LNG.

The aggregation of multiple small customers, however, either in the same country (as in Jamaica and Dominican Republic) or through a "hub and spoke" model, as being promoted by AES and New Fortress Energy, can lead to higher infrastructure utilisation, and reduce costs of supply to levels where it can easily compete with liquid fuels, bringing both economic and environmental benefits.

A hub and spoke model, with multiple export and import points will require a concerted effort from exporting and importing countries to avoid unnecessary and expensive double taxation, and conflicting regulatory frameworks. A hub and spoke model will also require that LNG suppliers accept flexible destination clauses, although this appears to be becoming the norm in the industry, particularly for exports from the US, but also following a recent ruling by the Japanese Fair Trade Commission.

In order to address the issue of non-investment grade and speculative sovereign credit rating, governments and project sponsors might need to either incorporate the risk in the project economics and/or coordinate finance and political risk coverage with multilateral institutions such as the International Finance Corporation (IFC), Interamerican Development Bank (IDB) and the World Bank

Similarly to what was implemented in Panama, capacity payment mechanisms are necessary to anchor LNG-to-power projects in markets with a large share of renewable energy, in particular hydroelectric power plants, since the level of dispatch of gas-fired power will be unpredictable. This will also require LNG suppliers to be prepared to provide flexible LNG supply. In the case of the Caribbean, giving the proximity to large and flexible LNG quantities from the US Gulf this should not be problematic, but may prove more difficult in other regions of the world.

As in the case of DR, Panama and Jamaica, the existence of a demand aggregator is necessary to allow other smaller consumers to purchase LNG and mitigate Buyer credit risk.

Where projects have succeeded, it has required strong support from the host government, but the existence of natural monopolies for an incumbent owner of natural gas infrastructure poses regulatory challenges which governments will need to address. Government support should extend beyond the power market, to also facilitating the development of physical or virtual distribution infrastructure to supply other market players such as industrial consumers, hotels and commercial premises.

In short, the success of some countries in the Caribbean in being able to start LNG imports at small scale and use initial imports as a basis for further development provides a good example and provides useful lessons regarding suitable approaches to be deployed in other small markets. 

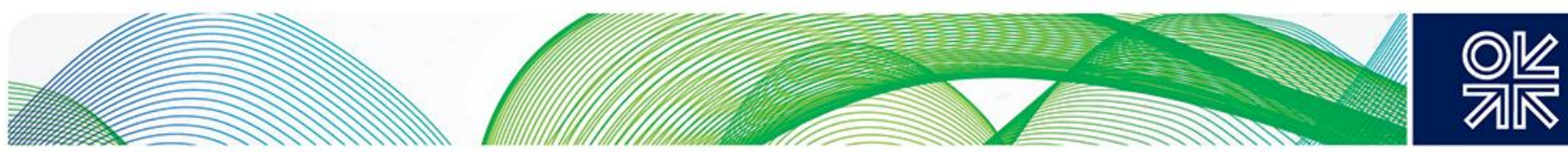

\section{Appendix}

Table 4: Caribbean and Central America: demographics and generation capacity

\begin{tabular}{|c|c|c|c|c|}
\hline Country & $\begin{array}{l}\text { Population } \\
\text { million }\end{array}$ & (2017) & $\begin{array}{l}\text { Installed } \\
\text { capacity } \\
\text { MW (2014) }\end{array}$ & kW/inhabitant \\
\hline \multicolumn{5}{|l|}{ Caribbean Islands } \\
\hline Cuba & 11.39 & & 6169 & 542 \\
\hline Haiti & 10.98 & & 244 & 29 \\
\hline Dominican Republic (2016) & 10.77 & & 3741 & 343 \\
\hline Puerto Rico & 3.68 & & 5839 & 1641 \\
\hline Jamaica & 2.81 & & 923 & 336 \\
\hline Trinidad and Tobago & 1.37 & & 2155 & 1898 \\
\hline Guadeloupe & 0.47 & & 509 & 1050 \\
\hline Bahamas & 0.40 & & 438 & 1450 \\
\hline Martinique & 0.40 & & 492 & 1242 \\
\hline Barbados & 0.29 & & 239 & 871 \\
\hline \multicolumn{5}{|l|}{ Saint Lucia } \\
\hline \multicolumn{5}{|l|}{ Curacao } \\
\hline & 0.16 & & 33 & 206 \\
\hline Saint Vincent \& Grenadines & 0.11 & & 58 & 528 \\
\hline Grenada & 0.11 & & 49 & 454 \\
\hline United States Virgin Islands & 0.11 & & 316 & 3012 \\
\hline Aruba & 0.10 & & 230 & 2754 \\
\hline Antigua and Barbuda & 0.09 & & 118 & 897 \\
\hline Dominica & 0.07 & & 24 & 368 \\
\hline Cayman Islands & 0.06 & & 132 & 2144 \\
\hline Saint Kitts and Nevis & 0.06 & & 56 & 1110 \\
\hline Sint Maarten & 0.04 & & 97 & 2418 \\
\hline Turks and Caicos Islands & 0.04 & & 75 & 2229 \\
\hline British Virgin Islands & 0.03 & & 44 & 1442 \\
\hline Anguilla & 0.01 & & 33 & 1878 \\
\hline Montserrat & 0.01 & & 6 & 965 \\
\hline \multicolumn{5}{|l|}{ Central America } \\
\hline Belize & 0.37 & & 143 & 382 \\
\hline Panama & 4.00 & & 3369 & 799 \\
\hline Costa Rica & 4.90 & & 3068 & 626 \\
\hline El Salvador & 6.17 & & 1670 & 271 \\
\hline Nicaragua & 6.20 & & 1331 & 215 \\
\hline Honduras & 8.30 & & 1852 & 294 \\
\hline Guatemala & 16.54 & & 4205 & 206 \\
\hline Total & 90.23 & & 37736 & \\
\hline
\end{tabular}

Source: (United Nations, 2014), (Worldometers, 2017) 

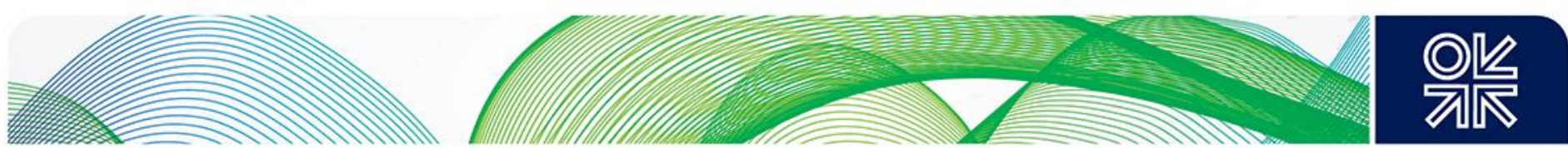

Table 5: Caribbean and Central America: power generation capacity and gas supply potential ${ }^{98}$

Country

Aruba

Anguilla

Antigua \& Barbuda

Bahamas

Barbados

BVI

Dominica

Dominican Republic*

Grenada

Guadeloupe

Haiti

Jamaica

Montserrat

Puerto Rico

Saint Lucia

St Kitts \& Nevis

Sint Maarten

St Vincent \&

Grenadines

Trinidad

Turk \& Caicos

US Virgin Islands

Total Caribbean

Central America

Belize

Costa Rica

El Salvador

Guatemala

Honduras

Nicaragua

Panama

Total Central America

Total Region
MW

230

33

118

438

239

44

24

3741

49

509

244

923

6.2

5839

78.4

56

97

58

2155

75

316

15085

MW

143

3068

1670

4205

1852

1331

3369

15466

30551

\section{Oil share (\%)}

84.6

99.9

99.9

100

100

100

71.4

61.4

98.8

51.5

85

94.1

100

71.8

99.9

94.3

97

78

1

99.6

80

Gas potential (Bcma)

195

33

118

438

239

44

17

2182

48

262

207

869

6

4192

78

53

94

45

22

75

253

9470

MW

$60.4 \quad 86$

$19.4 \quad 595$

$45.3 \quad 757$

$23 \quad 967$

$46.2 \quad 856$

$53.9-717$

$33.1-1115$

5152

14621

Source: (NREL - Department of Energy, 2016), (CNEE Guatemala, 2017), (Pro Honduras, 2017), (Secretaria Nacional de Energia - Panama (b), 2015)

(*) 3314 MW effective

${ }^{98}$ Figures do not include Cuba, Cayman Islands, Curacao and Martinique due to lack of updated data. 

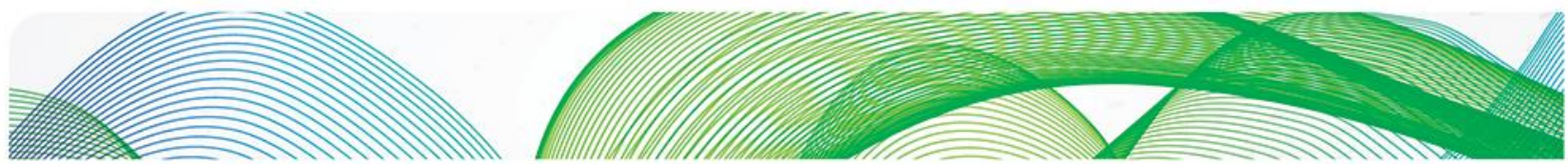

\section{O倸}

Table 6: Credit rating of select Caribbean and Central America countries

\begin{tabular}{|l|l|}
\hline Country & Credit Rating (S\&P) \\
\hline Barbados & BBB+ \\
\hline Belize & CCC \\
\hline Costa Rica & B- \\
\hline Dominican Republic & BB- \\
\hline Guatemala & BB- \\
\hline Grenada & BB- \\
\hline Montserrat & SD \\
\hline Nicaragua & BBB- \\
\hline Panama & B + \\
\hline Puerto Rico & BBB \\
\hline Trinidad \& Tobago & D \\
\hline & BBB + \\
\hline
\end{tabular}

Source: https://tradingeconomics.com/country-list/rating 

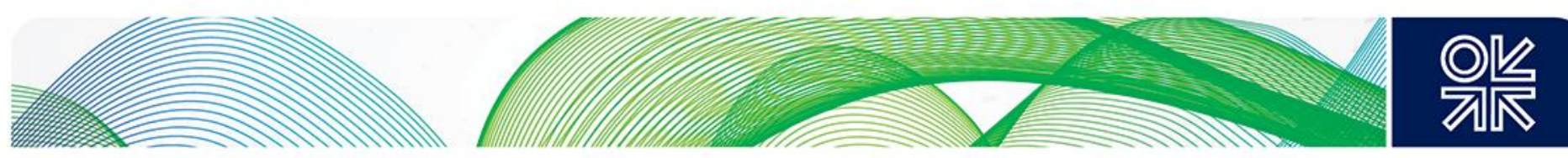

\section{Bibliography}

AES Dominicana. (2016). Final Offering Memorandum. Retrieved from http://aesmcac.com/aesdominicana/wp-content/uploads/2016/08/AES_Dominicana__Final_Offering_Memorandum.pdf

Attwood \& Mercados. (2013). Development of a Legal and Regulatory Framework for the Gas Sector. Retrieved from Ministry of Science, Technology, Energy and Mining, Jamaica: http://mset.gov.jm/sites/default/files/pdf/Regulatory\%20Framework\%20for\%20the\%20Gas\%20Sector -1.pdf

Bailey, J. J. $(2013,12)$. IADB. Retrieved from Interamerican Development Banks: https://publications.iadb.org/handle/11319/6015?locale-attribute=en

Bolinaga, M. (2017, 04). Gas Natural para Costa Rica: Una realidad. Retrieved 09 12, 2017, from CICR: http://www.cicr.com/wp-content/uploads/2017/04/Cl2-Miguel-Bolinaga-AES.pdf

CNEE Guatemala. (2017). Informe Estadistico 2016. Retrieved 2017, from Comisión Nacional de Energía Eléctrica.

Di Bella, G. e. (2015). Energy Subsidies in Latin America and the Caribbean: Stocktaking and Policy Challenges. Retrieved from IMF: https://www.imf.org/external/pubs/ft/wp/2015/wp1530.pdf

FINET. (2017). Fondo de Inversion Nacional en Electricidad y Telefonia. Retrieved from http://www.fisdl.gob.sv/temas-543/oferta-programatica/sistema-de-proteccion-social-universal/fondode-inversion-nacional-en-electricidad-y-telefonia\#.WfyVPBxl-yl

IGU. (2017). 2017 World LNG Report. Barcelona: International Gas Union. Retrieved from http://www.igu.org/sites/default/files/103419-World_IGU_Report_no\%20crops.pdf

Indiga. (n.d.). Retrieved from http://indiga.us/map-of-central-america-jamaica/map-of-americajamaica-tenbergfotografie - THIS SITE CANNOT BE REACHED!

Lluberes, J. (2015). Proyecto Terminal LNG. Retrieved from Slideshare: https://es.slideshare.net/amchamdr/presentacin-juan-vicini-en-san-pedro-45889873

Ministerio de Energia y Minas - Guatemala. (2017). Estadisticas. Retrieved 09 18, 2017, from http://www.mem.gob.gt/estadisticas/

Moreno, L. F. (2017). Proyecto de Ley de Gas Natural. Retrieved from Secretaria de Energia Panama:http://www.energia.gob.pa/tmp/file/521/PROYECTO\%20DE\%20LEY\%20DE\%20GAS\%20N ATURAL\%20PANAMA\%20JULIO\%2012.pdf

Navarrete, M. R. (2017). Estadisticas del Subsector electrico de los paises de los paises del Sistema de la Integracion Centroamericana 2015. Retrieved 09 18, 2017, from Repositorio CEPAL: http://repositorio.cepal.org/bitstream/handle/11362/40910/1/S1700038_es.pdf

NREL - Department of Energy. (2016). Island Energy Snapshots. Retrieved from https://energy.gov/eere/island-energy-snapshots

OEA \& NREL. (2012). Energy Policy and Sector Analysis in the Caribbean (2010-2011). Retrieved from Caricom: http://cms2.caricom.org/documents/13193-Iccc_report_final_may2012.pdf

Pro Honduras. (2017). Perfil Setor Energia Honduras 2016. Retrieved 09 18, 2017, from https://www.direcon.gob.cl/wp-content/uploads/2017/03/Honduras_06_perfil_sectorial_energia.pdf

Secretaria Nacional de Energia - Panama (b). (2015). Plan Energetico Nacional 2015-2050. Retrieved from http://www.energia.gob.pa/tmp/file/277/plan\%20energetico\%20nacional\%20-edicion\%20ira\%20julio\%202016.pdf 

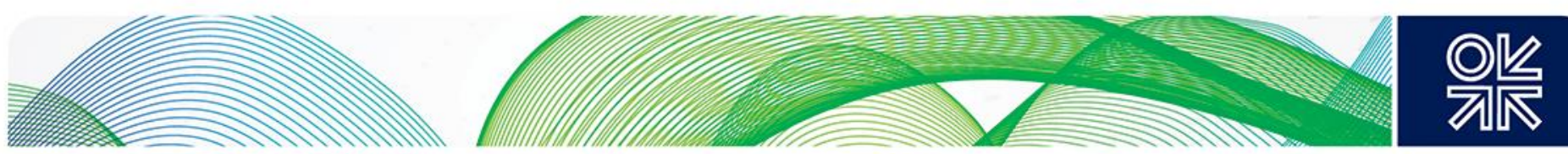

Secretaria Nacional de Energia (a). $(2017,06)$. El Mercado Eléctrico de la República de Panamá. Retrieved from http://www.energia.gob.pa/tmp/file/311/Sector\%20Electrico\%20\%20Panama,\%20151231.pdf

Songhurst, B The Outlook for Floating Storage and Regasification Units (FSRUs) OIES, 2017.

The Economist Intelligence Unit. (2015). El futuro del sector electrico en la Republica Dominicana. Retrieved from FUNGLODE: http://www.funglode.org/wpcontent/uploads/2015/10/EIU_Funglode_SP_PRINT.pdf

United Nations. (2014). UN Energy Statistics. Retrieved 09 11, 2017, from United Nations Statistics Division: http://data.un.org/Data.aspx?d=EDATA\&f=cmID\%3AEC

http://www.worldbank.org/en/region/lac/overview

Worldometers. (2017). Countries in Latin America and the Caribbean by population (2017). Retrieved 09 13, 2017, from http://www.worldometers.info/population/countries-in-latin-america-and-thecaribbean-by-population/ 